\title{
RECEIVED
}

FEB 221996

$$
\text { OSTI }
$$

\section{Commercial Low-Level Radioactive Waste Transportation Liability and Radiological Risk}

National Low-Level Waste Management Program

August 1992

\section{MASTER}




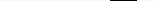




\title{
Commercial Low-Level Radioactive Waste Transportation Liability and Radiological Risk
}

\author{
G. J. Quinn \\ O. F. Brown II \\ R. S. Garcia
}

August 1992

Idaho National Engineering Laboratory

EG\&G Idaho, Inc.

National Low-Level Waste Management Program

Idaho Falls, Idaho 83415 


\begin{abstract}
This report was prepared for States, compact regions, and other interested parties to address two subjects related to transporting low-level radioactive waste to disposal facilities. One is the potential liabilities associated with low-level radioactive waste transportation from the perspective of States as hosts to low-level radioactive waste disposal facilities. The other is the radiological risks of low-level radioactive waste transportation for drivers, the public, and disposal facility workers.
\end{abstract}

\title{
DISCLAIMER
}

This report was prepared as an account of work sponsored by an agency of the United States Government. Neither the United States Government nor any agency thereof, nor any of their employees, makes any warranty, express or implied, or assumes any legal liability or responsibility for the accuracy, completeness, or usefulness of any information, apparatus, product, or process disclosed, or represents that its use would not infringe privately owned rights. Reference herein to any specific commercial product, process, or service by trade name, trademark, manufacturer, or otherwise does not necessarily constitute or imply its endorsement, recommendation, or favoring by the United States Government or any agency thereof. The views and opinions of authors expressed herein do not necessarily state or reflect those of the United States Government or any agency thereof. 



\section{EXECUTIVE SUMMARY}

Transportation of low-level radioactive waste (LLW) to commercial disposal facilities involves potential liability from accidents and potential radiological risks of personal injury or financial loss. Most LLW is transported by exclusive-use trucks on the nation's highways. Some LLW is transported by rail, and rarely is LLW transported via water. LLW is not transported by air. Regulations that evolved during the past few decades have established a rigorous set of standards intended to prevent accidents that would have serious radiological consequences due to the radioactive nature of the materials being transported. Still, a remote potential exists for costly liabilities as a result of LLW transportation accidents if significant amounts of radioactive contaminants were released. The radiological risks resulting from such accidents can be quantified using sophisticated risk analysis methods.

However, the same analysis methodology shows that the radiological risk from potential accidents due to a specified set of LLW shipments would be less than the radiological risk corresponding to the normal (incident-free or routine) transport operations for the set of shipments. This is because routine shipments result in many very small doses to numerous persons along a route (e.g., in passing cars, along roads, or in buildings). Although each small dose to an individual from a routine shipment is insignificant in comparison to an average annual radiation dose each person normally receives, these many small incremental doses to individuals are summed to obtain a population dose for a shipment. When a set of LLW shipments is evaluated using transportation risk analysis methods, the total population dose expected from routine operations for the shipments is also a measure of the risk of long-term health effects from incident-free shipments. The incident-free risk from a set of LLW shipments calculated in this manner is much larger than the expected risk determined for potential accidents for the same set of shipments.

In communicating the relative risk of LLW shipments to the public, the potential for serious accidents creates concerns because potentially significant consequences are the focus of discussions, and the small probability of catastrophic consequences does not place radiological risk into perspective. Historically, accidents with harmful consequences have not occurred during transport of LLW. Since this does not mean such accidents could absolutely not occur, States and compact regions should be cognizant of potential liabilities for a State as a host to a LLW disposal facility. Similarly, States should be aware of the efforts already performed to determine the magnitude of radiological risks of LLW shipments to truck drivers, the public, and LLW disposal facility operators. Assistance is available from Sandia National Laboratories to States to calculate estimates of radiological risk for any set of LLW shipments of interest to a State.

The total radiological risk for LLW shipments is very low in comparison to other risks in modern society. As the severity of the radiological consequences predicted for LLW transportation accidents increases, the probability of such accidents occurring decreases. The risks from accidents involving LLW shipments are orders of magnitude less than the very low risks from incident-free LLW shipments. The incident-free risks to drivers and workers at LLW disposal facilities are higher than for an individual member of the public. Occupational exposures for these radiation workers need to be maintained as low as is reasonably achievable.

Despite stringent safety regulations applicable to LLW transportation, concern continues to be expressed about liabilities that might be incurred by States as hosts to a LLW disposal facility in the 
event of an accident. For example, States have expressed concern about potential liabilities to third parties for such damages as personal injuries to individuals involved in a transportation accident, destruction of property, cleanup costs, precautionary evacuations, environmental restoration, and emergency response costs (including investigation, defense, and settlement costs). The theories of environmental or tort liability applicable to damages resulting from a LLW transportation accident and their applicability to a particular State vary and will depend upon the law of that jurisdiction (including sovereign immunity provisions). Additionally, State liability may be covered under the Federal Price-Anderson system or private insurance. Thus, individual States need to review their own tort, environmental, and sovereign immunity laws and, if necessary, consider State legislation to address the gaps presented. This is especially so in such unclear areas as liability for emergency response and cleanup costs.

In the last 20 years, 53 transportation accidents in the United States involved commercial LLW, and only four of these accidents involved a release of LLW. This number does not include transportation accidents involving other radioactive materials (e.g., sealed sources, radiopharmaceuticals, and spent nuclear fuel). Also, this number does not include accidents due to handling during loading or unloading. Section 5 includes the scenarios and results for the commercial LLW transportation accidents.

This report presents information on the potential liabilities and radiological risks related to LLW transportation to assist interested States in considering these elements in planning for the development and operation of a LLW disposal facility. The intention is to provide a basic understanding of these subjects and present related issues that encourages States to consider the adequacy of their current position on a particular aspect and determine if additional actions are needed. This brief document does not offer comprehensive approaches for preparing for LLW transportation liability and radiological risk but assists in evaluating these elements as part of the planning process for a LLW disposal facility. 


\section{CONTENTS}

1. INTRODUCTION $\ldots \ldots \ldots \ldots \ldots \ldots \ldots \ldots \ldots \ldots \ldots \ldots \ldots \ldots \ldots \ldots \ldots \ldots \ldots \ldots$

1.1 Commercial LLW Sources and Forms $\ldots \ldots \ldots \ldots \ldots \ldots \ldots \ldots \ldots \ldots \ldots$

2. REGULATORY FRAMEWORK $\ldots \ldots \ldots \ldots \ldots \ldots \ldots \ldots \ldots \ldots \ldots \ldots \ldots \ldots$

3. LIABILITY FOR LLW TRANSPORTATION $\ldots \ldots \ldots \ldots \ldots \ldots \ldots \ldots \ldots \ldots$

3.1 Liability for Injuries to Persons and Property $\ldots \ldots \ldots \ldots \ldots \ldots \ldots \ldots$

3.1.1 Applicability to the States $\ldots \ldots \ldots \ldots \ldots \ldots \ldots \ldots \ldots \ldots \ldots \ldots$

3.1.2 Provisions in Interstate LLW Compacts ................ 10

3.1.3 Damages Recoverable . . . . . . . . . . . . . . . . . . 11

3.2 Liability for Evacuation and Relocation Costs $\ldots \ldots \ldots \ldots \ldots \ldots \ldots$

3.3 Liability for Emergency Response Costs $\ldots \ldots \ldots \ldots \ldots \ldots \ldots \ldots$

3.4 Liability for Environmental Cleanup . . . . . . . . . . . . . . . 14

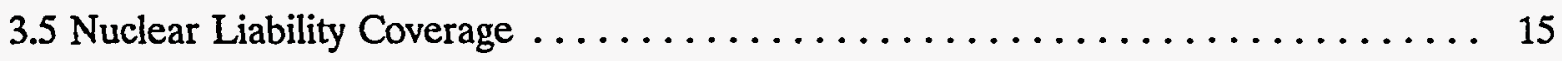

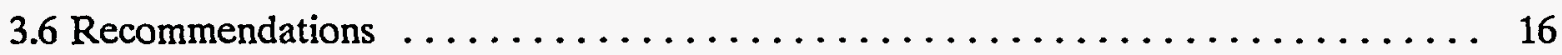

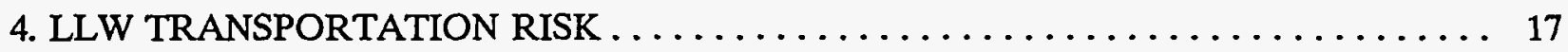

4.1 Estimating $\mathrm{LLW}$ Transportation Risks $\ldots \ldots \ldots \ldots \ldots \ldots \ldots \ldots \ldots \ldots \ldots$

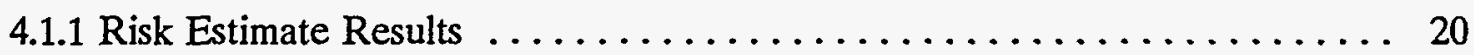

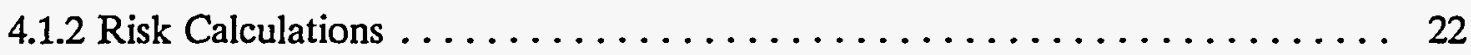

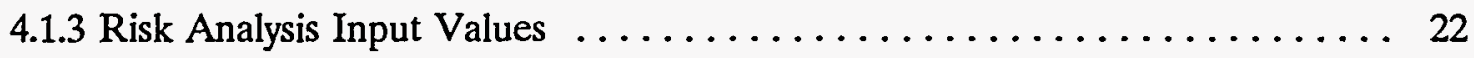

4.2 NUREG-0170 Results of Using RADTRAN $\ldots \ldots \ldots \ldots \ldots \ldots \ldots \ldots$

4.2.1 Incident-Free and Accident Risks $\ldots \ldots \ldots \ldots \ldots \ldots \ldots \ldots \ldots \ldots$

4.2.2 Risks to Drivers, the Public, and Disposal Facility Workers ......... 28

4.2 .3 Economic Consequences . . . . . . . . . . . . . . . . . 29

4.2.4 Worst-Case Accident Results . . . . . . . . . . . . . . . 29

4.3 Applicability of NUREG-0170 Results to Current LLW Shipments $\ldots \ldots \ldots \ldots$

4.4 RADTRAN Results for LLW Shipments $\ldots \ldots \ldots \ldots \ldots \ldots \ldots \ldots \ldots \ldots$

4.5 More on Transportation Risk Analysis Methodologies $\ldots \ldots \ldots \ldots \ldots \ldots \ldots$ 


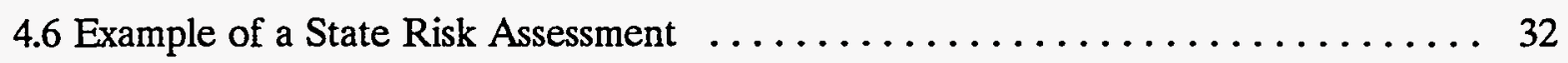

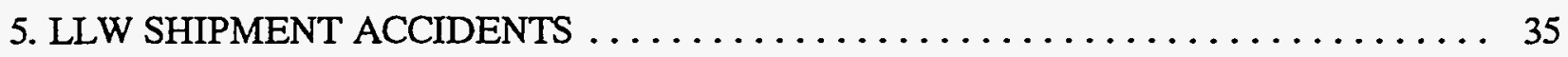

5.1 Transportation of Commercial Low-Level Radioactive Waste . . . . . . . . 35

5.2 Transportation Accidents Involving Commercial LLW $\ldots \ldots \ldots \ldots \ldots \ldots$

5.3 Transportation Accident Conclusions $\ldots \ldots \ldots \ldots \ldots \ldots \ldots \ldots \ldots \ldots$

6. SUMMARY $\ldots \ldots \ldots \ldots \ldots \ldots \ldots \ldots \ldots \ldots \ldots \ldots \ldots \ldots \ldots \ldots \ldots \ldots \ldots \ldots$

7. REFERENCES $\ldots \ldots \ldots \ldots \ldots \ldots \ldots \ldots \ldots \ldots \ldots \ldots \ldots \ldots \ldots \ldots \ldots \ldots \ldots$

8. BIBLIOGRAPHY $\ldots \ldots \ldots \ldots \ldots \ldots \ldots \ldots \ldots \ldots \ldots \ldots \ldots \ldots \ldots \ldots \ldots$

Appendix A-Transportation Accidents Involving LLW Without Releases of LLW ...... A-1 FIGURES

1. Volume of LLW from all sources. Data provided by the Department of Energy's Manifest

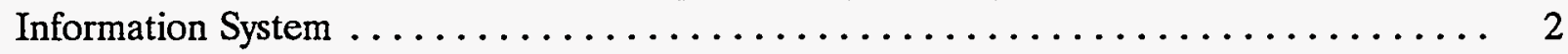

2. Comparison of all shipments of all commodities to number of shipments of hazardous and radioactive materials shipments in the United States each year $\ldots \ldots \ldots \ldots \ldots \ldots$

\section{TABLES}

1. Shipment summary and risks results $\ldots \ldots \ldots \ldots \ldots \ldots \ldots \ldots \ldots \ldots \ldots \ldots$

2. Estimated annual incident-free doses to crews for waste shipments $\ldots \ldots \ldots \ldots \ldots$

3. Estimated annual incident-free doses to the public for waste shipments $\ldots \ldots \ldots \ldots$

4. Estimated annual LLW shipments to Clark County, Illinois . . . . . . . . . . 34

5. Transportation accidents involving commercial LLW, $1971-1991 \ldots \ldots \ldots \ldots \ldots \ldots$ 


\section{ACRONYMS}

AEC Atomic Energy Commission

ALARA as low as reasonably achievable

CFR Code of Federal Regulations

DOE U. S. Department of Energy

DOT U. S. Department of Transportation

DSHS Department of Social and Health Services

HMR Hazardous Materials Regulations

LCF latent cancer facilities

LLW low-level radioactive waste

LSA low specific activity

NEPA National Environmental Policy Act

NRC U. S. Nuclear Regulatory Commission

RMIR Radioactive Material Incident Report

SCO surface-contaminated objects

SNL Sandia National Laboratories

TI Transport Index 



\section{Commercial Low-Level Radioactive Waste Transportation Liability and Radiological Risk}

\section{INTRODUCTION}

Beginning January 1, 1993, the Low-Level Radioactive Waste Policy Amendments Act of 1985 makes States responsible for managing low-level radioactive waste (LLW) generated within their borders. Some States formed compact regions to jointly manage LLW generated in all member States of that compact region.

Most States and compact regions will not be able to establish access to permanent disposal capacity for their LLW by the 1993 deadline. As a result, many States have begun examining alternative techniques to manage LLW while developing a permanent disposal facility. One of the options being considered is temporary storage of LLW at either the point of waste generation or at the point of waste collection. Another option is temporary storage at any of several centralized temporary storage facilities. These options may entail transporting LLW from generators to temporary storage to disposal.

States that transport the small amounts of LLW generated by State facilities face different potential liabilities and radiological risks than those risks associated with operating a disposal facility.

In considering potential liabilities and radiological risks for transport of LLW, the range of hazards associated with such shipments is important and is determined by many variables. The information discussed below identifies basic elements for LLW transportation liability and radiological risk. This report does not identify a minimum set of conditions that would ensure adequate preparations by a State or disposal facility operator to address all potential concerns. Each State should assess whether further action is needed on an individual basis.

\subsection{Commercial LLW Sources and Forms}

Commercial low-level radioactive wastes are generated by various sources; the largest contributors to LLW volume are nuclear utilities. ${ }^{1}$ Other contributors to commercial LLW generation include industrial users, universities, and hospitals. Figure 1 shows a breakdown of LLW sources in the United States for 1990. LLW from nuclear power plants includes ion-exchange resins, concentrated liquids, filter sludge, cartridge filters, trash, and waste from decommissioning. Industrial LLW may include discarded smoke detectors, air filters, gauges, and radioactive sources. Waste from universities may include biological waste from the use of radioactive materials in research. LLW from hospitals may include rags, filter papers, plastic, glass, syringes, bedclothes, or metal containers and equipment.

Low-level radioactive waste disposed at commercial disposal sites must meet requirements established by the U.S. Nuclear Regulatory Commission and disposal site operators. For example, all liquid wastes from all sources must be solidified before disposal. ${ }^{2}$ Most of the solid waste from all sources mentioned above is reduced by compaction or incineration. 


\section{Low-Level Radioactive Waste Received at}

Commercial Disposal Sites (1990)

\begin{tabular}{l}
$\begin{array}{l}\text { Generator } \\
\text { Category }\end{array}$ \\
\hline Academic \\
Government \\
Industrial \\
Medical \\
Utility
\end{tabular}

Total

\begin{tabular}{c}
$\begin{array}{c}\text { Volume } \\
\left(\mathrm{ft}^{3}\right)\end{array}$ \\
\hline $48,555.10$ \\
$72,353.51$ \\
$356,343.98$ \\
$22,792.13$ \\
$642,765.20$ \\
\hline
\end{tabular}

$1,142,809.92$

$$
\begin{array}{r}
\begin{array}{r}
\text { Activity } \\
\text { (Curies) }
\end{array} \\
\hline 1,096.04 \\
10,151.86 \\
102,855.67 \\
59.45 \\
433,738.88 \\
\hline 547,901.89
\end{array}
$$

Volume percentage by source (Percentages $<0.1 \%$ are not displayed)

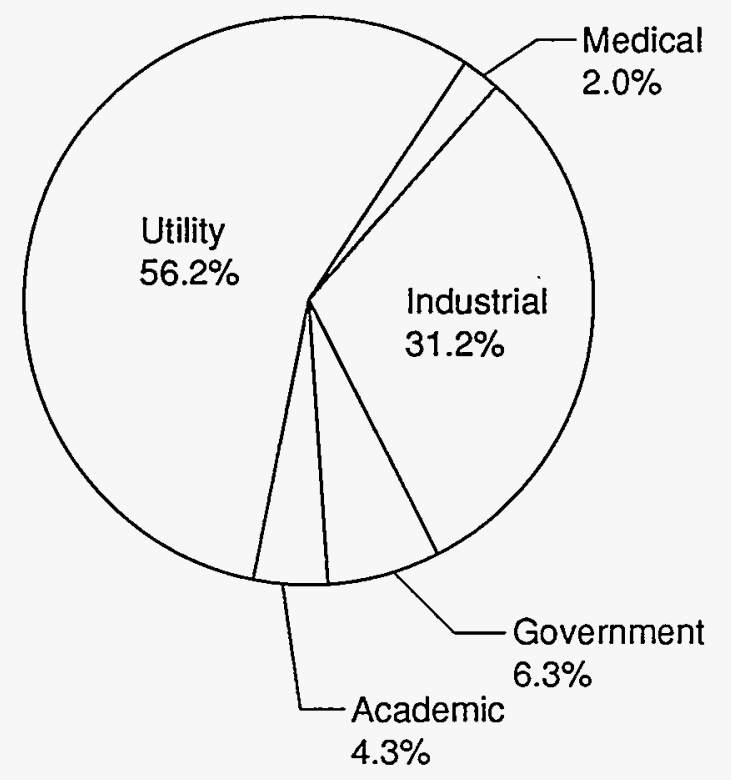

Activity percentage by source (Percentages $<0.1 \%$ are not displayed)

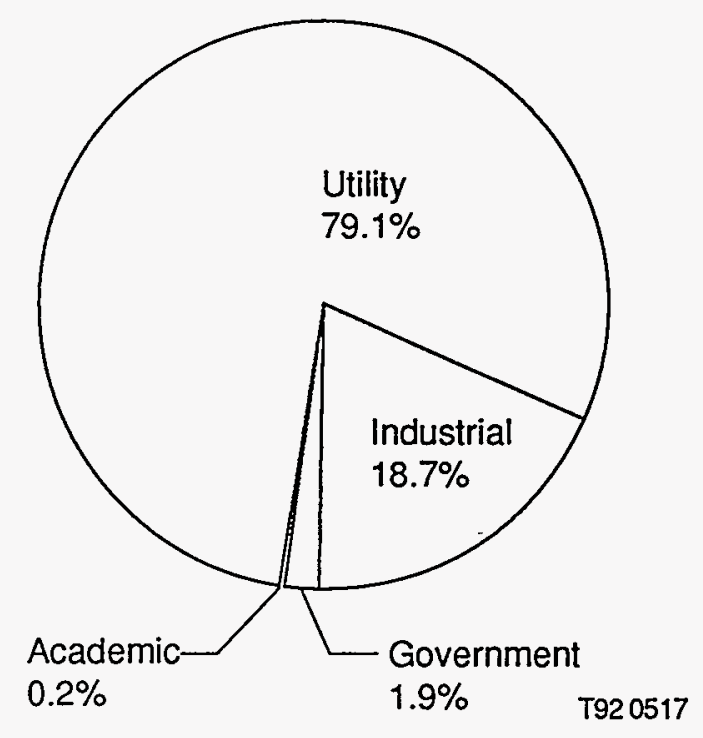

Figure 1. Volume of LLW from all sources. Data provided by the Department of Energy's Manifest Information System. ${ }^{3}$ 
The purpose of the stringent requirements on waste forms is to ensure a stable and acceptable waste form at the time of disposal. In addition to the minimum requirements, Class $\mathrm{B}$ and $\mathrm{C}$ wastes are required to have structural stability. To ensure that Class B and $C$ wastes will maintain stability, there are certain conditions that the waste must adhere to including:

- The waste should be in a solid form or in a container that provides structural stability after disposal.

- The waste should not contain free standing and corrosive liquids.

- The waste or container should be resistant to degradation due to radiation effects.

- The waste or container should be resistant to biodegradation.

- The waste or container should remain structurally stable under the compressive loads inherent in the disposal environment.

- The waste or container should remain structurally stable if exposed to moisture or water after disposal.

- The as-generated waste should be compatible with the solidification medium or container.

The requirements for long-term stability of LLW for disposal are an additional safety consideration during transport of LLW. The disposal requirements impose restrictions to the dispersibility of the waste and in effect protect the waste form in transit from potential releases of material in the event of a transportation accident. 


\section{REGULATORY FRAMEWORK}

LLW transportation liability and radiological risk are directly related to safety of LLW shipments. The safety of LLW shipments is largely due to the adherence to existing Federal and State regulations. Packaging LLW for transport in compliance with these safety regulations reduces chances for serious radiological accidents and therefore lowers potential liability and radiological risk of personal injury or loss in accidents. These safety requirements include rigorous rules to ensure packages for transport of LLW are designed to survive severe traffic accidents if the characteristics of a LLW material pose a serious radiological hazard from releases in an accident.

Legislation, regulations, and implementation guidance for transport of LLW have a long history of continuous development. Federal regulations for transport of radioactive materials, which include LLW, are part of the Hazardous Materials Regulations (HMR) promulgated by the U.S. Department of Transportation (DOT). The HMR are issued pursuant to the Hazardous Materials Transportation Act of 1974, as amended. The HMR govern the safety aspects of hazardous materials transportation and include requirements for classification, packaging, hazard communication, handling, transport, and incident reporting.

Of necessity, the HMR are complex. They address the legal, technical, and operational safety requirements for transport of thousands of hazardous constituents. The HMR apply to transportation of hazardous material in commerce, including LLW shipments. The HMR contain standards for preemption of State, political subdivision, and Native American Indian tribe requirements that are either (a) not "substantially the same" as Federal requirements, (b) exclusively a "covered subject" in the Federal rules, or (c) "highway routing" requirements. The preemption standard is intended to clarify the relationship and avoid confusion between Federal and non-Federal laws governing the transportation of hazardous materials.

The following are brief descriptions of some of the DOT's transportation regulations. The subjects are covered by existing regulations in use for transport of hazardous materials, such as LLW shipments presently traveling to commercial LLW disposal facilities. The safety record using these regulations is excellent, as discussed in Section 5.

- Shipping Packaging Design-An empty shipping container for LLW is called a packaging, and a shipping container loaded with LLW is called a package. Packagings must meet performance requirements based upon the quantity and types of radionuclides in the LLW to be transported. Three main types of packagings presently exist:

- $\quad$ Strong, tight packages may be used for transport of low specific activity (LSA) wastes under the requirements in 49 CFR 173.425. LSA materials are considered inherently safe from a radiotoxicity point of view since it is not conceivable that in an accident a person could ingest enough LSA material to result in a significant radiological hazard. A wooden crate containing LLW that qualifies as LSA material is an example of a strong, tight package.

- Type A packagings may be used for up to a Type A quantity of radioactive material, according to 49 CFR 173.431. A Type A quantity of radioactive material is an amount of each radionuclide that would result in some, but only limited, radiological 
hazard in an accident. Type A packagings are sufficiently strong to withstand forces normally expected to occur during transportation as specified by a set of tests in 49 CFR 173.465. The tests include a free drop from four feet with the Type A packaging loaded with materials to simulate the proposed LLW contents. 55-gallon drums are typical Type A packagings suitable for Type A quantity shipments of many LLW materials.

- Type B packagings are required for some LLW shipments that must meet U.S. Nuclear Regulatory Commission (NRC) performance requirements for packaging integrity following a transportation accident. The NRC performance criteria are applicable to a packaging design if greater than a certain quantity of radioactive material is to be transported in a package, according to 10 CFR 71.0(a) (i.e., fissile material or greater than a Type A quantity of other radionuclides). NRC criteria apply if the radiological impact of failure of a packaging to provide containment, shielding, or subcriticality control for its LLW contents in an accident would present a radiological danger to a person or population near the location of the accident. An example of a Type B package would be a specially-designed cask made to meet requirements for shipping certain low-level radioactive wastes.

- The DOT has proposed changes to packaging requirements for transport of LSA materials. ${ }^{4}$ Under the proposed regulations, LSA and surface-contaminated objects (SCO) would be allowed to be transported in a new type of packaging called the "industrial package." Three categories of industrial package that meet differing packaging requirements would replace the strong, tight package. Note that DOT also proposed LSA package quantity limits to control external radiation levels produced as a result of a transportation accident (i.e., some material transported as LSA under present rules would be required to be transported in Type B packages under the proposed rules).

- Shipment Restrictions-Restrictions on some LLW shipments may be cost-effective and improve safety. For example, permits for oversize or overweight shipments sometimes include restrictions on travel or impose other conditions.

- Inspections and Enforcement-Inspections are performed for regulatory compliance at State borders, at weigh stations, and on roads for all types of shipments including trucks carrying LLW. Penalties are prescribed for noncompliance with administrative and safety requirements.

- Emergency Response-State and local governments have established and maintain emergency planning and response capability for accidents occurring in their jurisdictions. Organizations responsible for responses are identified, emergency response actions needed are preplanned, and routine training exercises are performed. When transportation accidents involve hazardous materials, including LLW shipments, in-State first responders to accidents are assisted by national organizations when requested.

- Shipment Notification-Federal requirements for notification of States regarding LLW shipments apply to some truck shipments of LLW that exceed certain quantities of 
radionuclides and are required to be transported in NRC approved, Type B shipping packages. When required by 10 CFR 71.97, States on a route are notified as specified in the regulations.

- Routing-Federal regulations ensure highway route controlled quantities of LLW are transported over "preferred routes" selected to reduce time in transit. Federal requirements will be expanded to include routing for all hazardous materials, including all LLW, in a future rulemaking. According to 49 CFR 177.825, States may designate a "preferred route" using the DOT's guidelines or an equivalent routing analysis that adequately considers overall risk to the public. The risks to drivers, LLW disposal facility workers, and the public from LLW transportation are discussed in Section 4.

- Incident Notification-Reporting requirements for the notification of Federal authorities regarding incidents during LLW shipments is a "covered subject" with rules specified in DOT regulations in $49 \mathrm{CFR}$ 171. Some non-Federal rules for accident notification of State and local authorities have been permitted under DOT inconsistency rulings.

- Financial Liability and Insurance-The minimum acceptable level of financial responsibility for hazardous materials shipments, including $L L W$, by motor carriers is specified in Federal regulations in 49 CFR 387. Insurance policies or surety bonds are required for LLW shipments to provide monetary coverage for incidents. Potential liabilities for States from LLW transportation accidents are discussed in Section 3.

- Driver and Operator Training-Federal requirements establish minimum qualifications and training needed for LLW carrier companies and drivers in 49 CFR 177.825 .

The above information on regulations related to transport of LLW shows that safety is a major consideration at the national level. Federal regulations are under constant review and continue to be improved. 


\section{LIABILITY FOR LLW TRANSPORTATION}

Despite stringent safety regulations applicable to LLW transportation, concern continues to be expressed about liabilities that might be incurred by States as hosts to LLW disposal facilities in the event of a LLW shipping accident. For example, States have expressed concern about potential liabilities to third parties for such damages as personal injuries to individuals involved in a transportation accident, destruction of property, cleanup costs, precautionary evacuations, environmental restoration, and emergency response costs (including investigation, defense, and settlement costs). This section will review laws, regulations, and practices regarding liability for LLW transportation activities, as these generally apply to States and various State governmental organizations. A comprehensive review of all fifty States is beyond the scope of this document. However, the legal principles discussed in this report should provide a useful overview of a State's potential liability for LLW transportation activities.

\subsection{Liability for Injuries to Persons and Property}

Civil liability for injuries to persons and property (i.e., torts) traditionally has been determined on a case-by-case basis in our judicial system. In other words, for the most part tort liability is based on common law principals rather than statutory law. (On the other hand, environmental laws, which may address cleanup of hazardous materials spills, usually are found in statutes and implementing regulations.) In our Federal system, tort law can vary significantly from State to $\bar{S}$ tate. However, there are certain principles that apply nationwide. For example, for there to be an action in tort, there must be an act or omission that causes compensable injury to another in violation of an obligation imposed by law.

Modern tort law generally classifies cases involving physical harm to persons and property according to the degree of fault inherent in the tortious conduct: intentional, negligent, and strict liability. Intentional torts are those resulting from acts committed (or omitted) with an intent to cause injury to another. Negligent torts are those resulting from conduct which falls below the standards established by law for the protection of others against unreasonable risks of harm. Strict liability torts are torts imposed without fault and arise in situations where an activity is sufficiently dangerous or creates sufficiently dangerous risks that the law requires it to be carried on at the actor's peril.

In the event of a transportation accident in which there is a release of LLW, tort liability for radiological injuries to persons and property may be determined in a particular State under the principles of negligence or strict liability, assuming the absence of intent to cause injury. Actions for radiological injuries to persons and property have been determined under all three classifications of torts. ${ }^{a}$ However, most courts apply strict liability principles in cases involving injuries to persons and

a. Early cases addressing radiological injuries to persons and property determined the liability question according to general principles of negligence law and held that the theory of strict liability was inapplicable [Bartholomae Corp. v. United States, 253 F.2d 716 (9th Cir. 1957)]. However, subsequent cases addressing radiological injuries to persons or property have considered the liability question under all three tort classifications. 
property resulting from accidents occurring in the transportation of hazardous materials. ${ }^{\mathrm{b}}$ On the other hand, where the transportation of hazardous materials is undertaken by a common carrier, courts in some States have applied a "public duty" exception and required a showing of negligence on the part of the common carrier. ${ }^{c}$ Still other courts have refused to apply strict liability standards in cases involving injuries to persons or property resulting from the transportation of hazardous materials. ${ }^{d}$ Ultimately, the theory of tort liability applicable to a case involving radiological injuries to persons or property resulting from a LLW transportation accident will depend upon the law of the applicable jurisdiction. Similarly, any liability for cleanup costs will depend on the law of the applicable jurisdiction.

In the event of a transportation accident in which there is no release of radioactive material (such as an accident involving transportation of an empty reusable packaging), tort liability for nonradiological injuries to persons and property likely would be determined in most jurisdictions under the principles of negligence, assuming the absence of intent to cause injury. (Without a release of radioactive material, there would be no cleanup requirements.)

\subsubsection{Applicability to the States}

While it is well settled that an action in tort may lie for injuries to persons or property resulting from the accidental exposure to radiation, the imposition of liability on a State for such exposure involves several preliminary issues. Two of these preliminary issues are examined below.

3.1.1.1 States as Defendants. A threshold matter is whether a State that operates a LLW disposal facility may be properly named as a defendant in connection with a LLW transportation accident. None of the nine interstate LLW compacts approved by Congress requires the compact States to provide transportation of LLW from the LLW generators to the regional disposal facilities. Accordingly, it is possible for transportation of LLW to be undertaken by commercial carriers engaged by private generators, by commercial carriers engaged by State generators, or by the States (or agents of the States) on behalf of private or State generators. If transportation of LLW is undertaken by commercial carriers engaged by private generators, State liability for damages resulting from accidents occurring in the course of the transportation of LLW should not exist under traditional tort concepts. In such a circumstance, the mere fact that a State is a compact member, a

b. Chavez v. Southern Pacific Transportation Co., 413 F.Supp. 1203 (E.D. Cal. 1976); Siegler v. Kuhlman, 81 Wash.2d 448, 502 P.2d 1181 (1972), cert. denied, 411 U.S. 983 (1973); but see, Indiana Harbor Belt Railroad Company v. American Cyanimid Company, 916 F.2d 1174 (7th Cir. 1990).

c. Southern Railroad Co. v. Adkins, 133 Ky. 219, 117 S.W. 321 (1909), reh. over., 133 Ky. 283, 119 S.W. 820 (1909); Pecan Shoppe of Springfield, Inc. v. Tri-State Motor Transit Co., 573 S.W.2d 431 (Mo. App. 1978); Pope v. Edward M. Rude Carrier Corp., 138 W.Va. 218, 75 S.E.2d 584 (1953); East Troy v. Soo Line Railroad Co., 409 F.Supp. 326 (E.D.Wis. 1976); Restatement (Second) of Torts § 521; but see, Chavez v. Southern Pacific Transportation Co., 413 F.Supp. 1203 (E.D. Cal. 1976); National Service Center, Inc. v. Gibbons, 319 N.W.2d 269 (Ia. 1982); Siegler v. Kuhlman, 81 Wash.2d 448, 502 P.2d 1181 (1972), cert. denied 411 U.S. 983 (1973).

d. Fritz v. E. I. du Pont de Nemours \& Co., 45 Del. 427, 75 A.2d 256 (1950). 
host to a regional disposal facility, or even an operator of a regional disposal facility should not give rise to State tort liability.

However, if transportation of LLW is undertaken by a commercial carrier engaged by a State generator an argument can be made for assessing tort liability against the State. In general, a State is not liable for torts committed by an independent contractor. However, this rule may not apply where the activity for which the independent contractor is engaged is "abnormally dangerous." In such

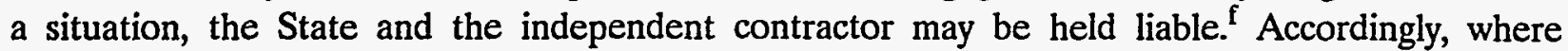
transportation of LLW is undertaken by a commercial carrier engaged by a state generator, it is possible that both the commercial carrier and the State could be held liable for injuries to persons and property resulting from a transportation accident. In such a situation, the State could be held liable not only for injuries to third parties but also for injuries to employees of the independent contractor. However, the liability of the State will depend on the extent to which it is not protected by sovereign immunity (see Section 3.1.1.2).

Although it is unlikely, if transportation of LLW is undertaken by the States (or agents of the States) on behalf of private or State generators, tort actions against the States may lie, depending on the extent to which the States are not protected by sovereign immunity (see Section 3.1.1.2).

3.1.1.2 Sovereign Immunity Issues. Historically, States have been immune from tort liability in their own courts for their acts or omissions or those of their officers, agents, employees, departments, agencies, and other instrumentalities. Thus, the tort liability of States has traditionally been governed by rules different from those applicable to individuals and private corporations. The doctrine of sovereign immunity from tort liability derives from medieval England and the concept that one could not sue the king in his own courts, hence the phrase "the king can do no wrong." The doctrine was transplanted in the United States and is implicitly recognized in the Eleventh Amendment to the U.S. Constitution, which grants States immunity from suit in Federal courts.

In recent years, there has been an erosion of the sovereign immunity doctrine in the United States. Many States have adopted tort claims acts or similar statutes that limit the traditional rules of sovereign immunity. State tort claims acts and similar statutes may be characterized generally as falling into two categories: first, an "open-ended" statutory scheme providing for liability subject to

e. If a State is an operator of a regional disposal facility, the State may be held liable for accidents occurring at the disposal facility. For example, accidents could occur in the transfer of LLW from the carrier to the disposal facility.

f. See dicta in Anderson v. Marathon Petroleum Co., 801 F.2d 936 (7th Cir. 1986) - "If a nuclear reactor blows up and thousands of people are irradiated, we would not allow the reactor company to slough off all liability for the accident onto a careless independent contractor, who, not having the resources to compensate the victims of his tort, had lacked adequate incentives to take care." But see, Blaber v. United States, 212 F.Supp. 95 (D.C.N.Y. 1962), affd., 332 F.2d 629 (2nd Cir. 1964) Atomic Energy Commission not responsible for injuries received by employees of independent contractor for damages for personal injuries arising out of explosions that occurred when one employee grasped a portion of thorium with a pair of tongs and placed it in a burning hood. 
stated exceptions for immunity, and second, a "closed-ended" statutory scheme providing for immunity subject to exceptions for liability.

It is necessary to carefully consult local statutory and constitutional provisions for the precise status of sovereign immunity in a State, since the scope and limitations of the various tort claims acts and similar acts vary significantly among the States and rarely cause a blanket abolition of immunity. Most States retain some limitation on liability based on the nature of the act or function involved, such as "governmental" or "proprietary," "discretionary," or "ministerial," or some combinations or variations of the two approaches, ${ }^{g}$ and many States impose specific limitations on the amount and nature of recovery permitted as well as detailed procedures for the presentation of claims, both administrative and judicial.

\subsubsection{Provisions in Interstate LLW Compacts}

While several of the interstate LLW compacts address the issue of State liability in the event of injury to persons or property resulting from the operation of a regional disposal facility, only the Northeast Compact specifically addresses whether a State may be held liable for damages resulting from accidents occurring in the transportation of LLW to such facilities. The Northeast Compact provides:

No non-host party state shall be liable for any injury to persons or property resulting from the operation of a regional facility or the transportation of waste to a regional facility; however, if the host state itself is the operator of the regional facility, its liability shall be that of any private operator. ${ }^{\text {h }}$

Accordingly, a non-host party State of the Northeast Compact region will not be liable for injuries to persons or property resulting from the transportation of waste to a regional facility. ${ }^{\mathrm{i}}$ Conversely, one would have to apply the various tort principles discussed above in determining the liability of the host State.

g. While each State might not reach the same conclusion, State operation of a LLW disposal facility probably would fall into the "proprietary" category, which usually involves a broader waiver of sovereign immunity than the "governmental" category.

h. Omnibus Low-Level Radioactive Waste Interstate Compact Consent Act, Pub. L. 99-240, 99 Stat. 1859, 1912-1913 (1986).

i. It should be noted that the two members of the Northeast Compact, New Jersey and Connecticut, are both host States.

j. On June 19, 1992, the U.S. Supreme Court declared unconstitutional the take title provision of $\$ 2021$ (d) (2) (C) of the Low-Level Radioactive Waste Policy Amendments Act of 1985. New York v. United States, No. 91-543 (U.S. slip opinion). The take title provision specified that a State that failed to provide for the disposal of all internally generated LLW by 1996 must, upon the request of the waste's generator or owner, take title to and possession of the waste and shall become liable for "all damages directly or indirectly incurred by such generator or owner as a consequence of the failure

(continued...) 
The other interstate LLW compacts are silent on the issue of State liability for damages resulting from accidents occurring in the transportation of LLW, although six of the nine interstate compacts provide generally that transporters of waste shall be liable for their acts, omissions, conduct or relationships in accordance with relevant laws (presumably including State sovereign immunity provisions). ${ }^{k}$

\subsubsection{Damages Recoverable}

Damage awards in tort suits involving the hazardous properties of various materials have been increasing dramatically over the last several years. Damage awards in tort suits involving radiation injury claims likewise have been increasing. In conjunction with this increase in damage awards in radiation injury litigation is an increase in the types of damages that courts have permitted in these cases. The following sections examine the potential damage recoveries in the event of tort liability resulting from an accident involving the transportation of LLW. These include compensatory and punitive damages, as well as attorneys' fees and litigation costs. Predicting the actual amounts of damages recoverable in a particular LLW transportation accident is beyond the scope of this document and cannot be done with actuarial precision in light of the very few LLW transportation accidents that have occurred to date.

3.1.3.1 Compensatory Damages. Various types of injuries to persons and damage to property may be sustained in connection with a LLW transportation accident. ' When a defendant's tort injures plaintiff's person or property, the plaintiff's basic remedy is compensatory damages. Thus, where a plaintiff proves a compensable injury to his person, he generally may recover all adverse physical and mental consequences of that injury, including medical expenses and lost wages or profits. Where a plaintiff proves a compensable injury to property that does not amount to conversion of the property, the plaintiff ordinarily may recover the difference between the value of the property before the tort and the value of the property after the tort, or, in the alternative, the reasonable costs of repair or restoration. Consistent with these general principles of compensatory damages, courts considering

j. (...continued)

of the State's to take possession of the waste...." The court did not address a State's potential liability for any other LLW activity (including transportation) under the 1985 Act or otherwise. Thus, while this recent Supreme Court decision may have yet unclear impacts on the continuing development of LLW disposal sites, it does not directly affect potential State liability under the tort and sovereign immunity doctrines discussed herein.

k. See the Appalachian States Low-Level Radioactive Waste Compact Consent Act, Pub. L. 100319, 102 Stat. 471, 480 (1988); and the Central, Southeast, Central Midwest, Midwest and Northeast Interstate Low-Level Radioactive Waste Compacts contained in the Omnibus Low-Level Radioactive Waste Interstate Compact Consent Act, Pub. L. 99-240, 99 Stat. 1859 (1986).

1. For example, LLW transportation accidents may involve personal injuries to the LLW shipment vehicle driver, passengers, and third parties and property damage to the LLW shipping package, the LLW shipping truck, other vehicles, and other physical property such as buildings, bridges, and guard rails. Damages for personal injuries and property damage resulting from a LLW transportation accident generally will be determined on the basis of compensatory damage principles. Liability for such damages will be determined on the basis of the foregoing discussion. 
cases involving radiological injuries to persons or property have permitted compensatory damages for such items as diminution in property value, ${ }^{\mathrm{m}}$ loss of profits, ${ }^{\mathrm{n}}$ increased cancer risk, ${ }^{\circ}$ and, in some circumstances, emotional distress. ${ }^{p}$ On the other hand, courts have not permitted local municipalities to recover the reduction in real property tax revenues resulting from a radiological accident. ${ }^{9}$

3.1.3.2 Punitive Damages. Unlike compensatory damages, punitive damages are not intended to compensate plaintiffs for injuries but to penalize defendants for actions beyond simple negligence. Again, standards vary from State to State; most States probably remain immune from punitive damages. However, the 1984 Supreme Court ruling in Silkwood v. Kerr-McGee Corp. ${ }^{\mathrm{r}}$ portends exposure to punitive damages even in cases where applicable radiation protection standards have been met (although an individual State may be insulated from punitive damages depending upon the extent to which it has waived sovereign immunity). In Silkwood, the court rejected arguments that the punitive damages award in the case was preempted as it conflicted with the Federal regulatory scheme and frustrated Congress' express desire to encourage widespread participation in the development and utilization of atomic energy for peaceful purposes. Although reversing the punitive damage award due to an erroneous jury instruction, the Court discredited challenges to the making of any such award altogether. Similarly, in In re Three Mile Island Litigation, ${ }^{\mathbf{s}}$ the court, in denying a defense motion

m. Westrom v. Kerr-McGee Chemical Corporation, No. 82 C 2034, slip opinion (N.D.Ill. October 4, 1983); Maryland Heights Leasing, Inc. v. Mallinckrodt, Inc., 706 S.W.2d 218 (Mo. App. 1985).

n. Maryland Heights Leasing, Inc. v. Mallinckrodt, Inc., 706 S.W.2d 218 (Mo. App. 1985); but see, General Public Utilities v. Glass Kitchens of Lancaster, Inc., 542 A.2d 567 (Pa. Super. 1988).

o. Brafford v. Susquehanna Corp., 586 F.Supp. 14 (D.C.Colo. 1984); but see, Westrom v. Kerr-McGee Chemical Corporation, No. 82 C 2034, slip opinion (N.D.Ill October 4, 1983); Maryland Heights Leasing, Inc. v. Mallinckrodt, Inc., 706 S.W.2d 218 (Mo. App. 1985); Good Fund, Ltd. - 1972 v. Church, 540 F.Supp. 519 (D.C.Colo. 1982); Silkwood v. Kerr-McGee Corp., 667 F.2d 908 (10th Cir. 1981), revd. on other grounds, 464 U.S. 238 (1984), reh. denied, 465 U.S., 1074 (1983), on remand, 769 F.2d 1451 (10th Cir. 1985), cert. denied, 476 U.S. 1104 (1986).

p. Field v. Philadelphia Electric Co., 565 A.2d 1170 (Pa. Super. 1989); but see, Bubash v. Philadelphia Electric Co., 717 F.Supp. 297 (M.D.Pa. 1989).

q. Pennsylvania v. General Public Utilities Corp., 710 F.2d 117 (3rd Cir. 1983).

r. Silkwood v. Kerr-McGee Corp., 667 F.2d 908 (10th Cir. 1981), revd. on other grounds, 464 U.S. 238 (1984), reh. denied, 465 U.S. 1074 (1984), on remand, 769 F.2d 1451 (10th Cir. 1985), cert. denied, 476 U.S. 1104 (1986).

s. In re Three Mile Island Litigation, 605 F.Supp. 778 (M.D.Pa. 1985). 
for partial summary judgment, held that punitive damages are available under the Price-Anderson Act (see part 3.4 below).' Also, in Field v. Philadelphia Electric Co.," the court reversed the trial court's decision to strike appellant's request for punitive damages in a case involving tortious radiological exposure.

3.1.3.3 Attorneys' Fees and Litigation Costs. Attorneys' fees and litigation costs associated with any tort case can be considerable. The universal American rule is that the prevailing party in tort litigation may not recover as damages attorneys' fees or other litigation costs in the absence of a statute expressly authorizing them. ${ }^{\mathrm{V}}$ State statutes typically provide for the recovery of minor litigation expenses, such as filing and service fees but little else. Thus, a State involved in any LLW transportation liability litigation usually would have to bear its own legal defense expenses.

\subsection{Liability for Evacuation and Relocation Costs}

In theory, evacuation and relocation costs may be awarded as compensatory damages in connection with tortious radiological injuries to persons or property. In most States, there is no recovery for purely economic injuries under negligence or strict liability theories. Thus, in Alloy Briquetting Corp. v. Niagara Vest, Inc., ${ }^{\text {w }}$ the court held that the plaintiff could not recover the cost of relocating its business due to alleged contamination of its leased properties. In theory, however, where a plaintiff has sustained injuries to person or property, any costs directly and proximately resulting from such injuries may be recovered. ${ }^{x}$ Conversely, where a plaintiff has not sustained injuries to person or property, recovery for economic injuries probably will not be allowed. Thus, unless persons who are evacuated or relocated can demonstrate injuries to person or property, the

t. Under the 1988 amendments to the Price-Anderson Act, no court may award punitive damages in any action with respect to a nuclear incident or precautionary evacuation where the United States Government is providing indemnification coverage. 42 U.S.C. $\S 2210($ s).

u. Field v. Philadelphia Electric Co., 565 A.2d 1170 (Pa. Super. 1989).

v. The Bush Administration recently has proposed that States adopt modifications of this rule in certain types of tort cases. See "Model State Award of Attorneys' Fees to Prevailing Party Act" (Feb., 1992).

w. Alloy Briquetting Corp. v. Niagara Vest, Inc., 756 F.Supp. 713 (W.D.N.Y. 1991).

x. In Pennsylvania v. General Public Utilities Corp., 710 F.2d 117 (3rd Cir. 1983), the court considered certain costs incurred by Pennsylvania and various municipalities in connection with the Three Mile Island incident. The claims for these costs were dismissed by the lower court on the ground that the losses claimed were "all purely economic losses." The plaintiffs argued, however, that the radioactive material emitted during the nuclear incident permeated the entire area, rendering the public buildings unsafe for a temporary period of time and constituting a physical intrusion on plaintiffs' properties, and that this was a sufficient showing to permit them to recover for damages flowing from such harm. Although expressing no opinion as to whether such a theory of damages might ultimately prevail, the court ruled that the plaintiffs should be permitted to develop the facts on which these contentions might be tested. 
costs of evacuation and relocation probably cannot be recovered under tort theories depending upon applicable State law.

\subsection{Liability for Emergency Response Costs}

A recurrent issue surrounding hazardous materials transportation is liability for costs associated with emergency response by police and fire departments in the event of an accident. Where the State is deemed liable for the transportation accident, the State will be responsible for its own emergency response costs incurred in responding to the transportation accident.

However, an issue remains as to whether a State would be liable for the emergency response costs of local government bodies. Ordinarily, a governmental unit cannot recover costs incurred in the performance of its governmental functions. Thus, it has been held that a governmental unit cannot recover costs incurred in fighting a fire, even where the fire results from negligence, absent statutory authority to maintain suit for the expenses. ${ }^{y}$ On the other hand, at least one court has recognized that a nuclear accident may present a unique type of hazard and that special rules of law may be appropriate to permit recovery of emergency response costs by State and local governmental entities. In Pennsylvania v. General Public Utilities Corp. ${ }^{2}$ the court vacated the dismissal of certain State and township plaintiffs' damage claims in connection with the Three Mile Island incident. The claimed damages consisted of (a) overtime, compensatory time, and other personnel costs incurred in responding to the incident; (b) operational expenses and emergency purchases incurred in responding; (c) lost work time as a result of the incident; and (d) other expenses incurred as a result of or in response to the incident. In any event, recovery of emergency response costs by a local governmental unit against the State will vary from State to State and, again, involve sovereign immunity issues.

In a case where the State is not deemed liable for the transportation accident but nevertheless incurs emergency response costs, the issue is whether the State may seek recovery of such costs from the liable party. Resolution of this issue involves the same considerations outlined above with respect to whether a municipality may recover from a State emergency response costs incurred in responding to a transportation accident for which the State is liable, except that sovereign immunity issues do not arise. In other words, liability for and ability to recover emergency response costs will vary from State to State; but, in most cases, they probably will not be recoverable, that is, each governmental entity usually will bear its own costs.

In cases where emergency response activities result in injuries to third parties, many States have enacted good samaritan laws. Where applicable, these laws limit the potential liability of entities that respond to a LLW transportation accident.

y. People v. Wilson, 240 Cal.App.2d 574, 49 Cal.Rptr. 792 (1966); Town of Howard v. Soo Line RR Co., 63 Wis.2d 500, 217 N.W.2d 329 (1974).

z. Pennsylvania v. General Public Utilities Corp., 710 F.2d 117 (3rd Cir. 1983). 


\subsection{Liability for Environmental Cleanup}

As a general rule, transporters of hazardous materials are required to clean up any hazardous materials discharged during a transportation accident. Such requirements are prescribed by various Federal and State statutes and regulations. ${ }^{\text {aa }}$ State financial liability for cleanup activities would vary from jurisdiction to jurisdiction and presumably would depend in large measure upon the State's actual involvement in the shipment. Thus, as in the case of tort liability, cleanup responsibility may turn on whether the State itself is the LLW shipper, the State arranges for the shipment, or the State has no direct involvement in the shipment. Liability for cleanup might more properly fall on the actual shipper. However, this assumes a non-State shipper would have assets sufficient to pay for the cleanup. If cleanup responsibility cannot be assigned to some entity other than the State, the State in which the accident occurs may end up paying for a cleanup that otherwise could present a hazard to human health or the environment. Furthermore, there has been considerable litigation over the last decade on the issue of whether environmental remediation constitutes "damages" within the meaning of comprehensive general liability insurance policies.

\subsection{Nuclear Liability Coverage}

In weighing potential liabilities, States and others should be mindful of the substantial amounts of nuclear liability or conventional insurance coverage applicable to most LLW shipments. ${ }^{\text {bb }}$ For example, certain shipments (including all shipments of LLW from nuclear power plants) are covered under the financial protection system established by the Federal Price-Anderson Act. ${ }^{c c} \mathrm{~A}$ unique feature of the Price-Anderson system is that, when it applies, it covers "anyone liable" (including a

aa. There has been increasing legislation at both the Federal and State levels regarding responsibility for cleanup of hazardous wastes. For example, the Comprehensive Environmental Response, Compensation, and Liability Act ("CERCLA"), 42 U.S.C. $\$ 9607$, provides that owners and operators of "facilities" from which there is a release of hazardous substances (excluding certain materials regulated under the Atomic Energy Act of 1954) shall be liable for all costs of removal or remedial action incurred by the United States or a State, any other necessary costs of response incurred by any other person, and damages for injury to, destruction of, or loss of natural resources. The statute is broad enough to apply to the release of hazardous substances occurring in a transportation accident since the term "facility" is defined to include a motor vehicle. In State of Idaho v. Southern Refrigerated Transport Inc., 1991 WL 22479 (D.Idaho 1991), a court held recently that an interstate trucking corporation was strictly liable under CERCLA for a release of hazardous substances occurring in a trucking accident since the trucking corporation was an owner/operator of a "facility" pursuant to the statute.

bb. The Appalachian States Low-Level Radioactive Waste Disposal Compact Consent Act, Pub. L. 100-319, 102 Stat. 471 (1988), requires host States to establish requirements for the purchase of insurance by carriers.

cc. 42 U.S.C. 2014, 2210. Note the Price-Anderson system leaves substantive tort law, to the States. This means that financial liability of shippers, carriers or others responsible for a radioactive packaging or transportation accident usually would be determined under applicable State law, just as it is for other types of packaging and transportation accidents. 
State, but not the Federal Government) for "any legal liability arising out of or resulting from a nuclear incident". This so-called "omnibus" feature would provide all entities liable with at least $\$ 7.445$ billion of coverage (as of August 1992). ${ }^{\text {dd }}$ Under the Price-Anderson Amendments Act of 1988, ${ }^{\text {ee }}$ the system specifically covers "precautionary evacuations", even if it later is determined there was not a release of radioactive material.

Some LLW shipments not covered by the Price-Anderson system are covered under "Facility Form" or "Supplier's and Transporter's Form" policies issued by the nuclear insurance pools (in amounts now up to $\$ 200$ million). These would include LLW shipments from many commercial, nonpower plant, NRC-licensed facilities. Conventional liability insurance may be available to cover any other shipments (such as radionuclides from medical facilities). States should review the insurance coverage applicable to particular LLW shipments because most should be adequate to compensate for any credible transportation accident scenario.

\subsection{Recommendations}

As indicated above, the theories of environmental or tort liability applicable to damages resulting from a LLW transportation accident and their applicability to a particular State will depend upon the law of that jurisdiction. Additionally, State liability may be covered under the Price-Anderson system or private insurance. Thus, individual States may wish to review their own tort, environmental, and sovereign immunity laws and, if necessary, consider State legislation to address the "gaps" presented. This is especially so in such unclear areas as liability for emergency response and cleanup costs.

dd. The Price-Anderson system also provides that the liability of all entities covered by it is limited to the amount of coverage provided by the system (now $\$ 7.445$ billion). This limitation-on-liability provision was upheld unanimously by the U.S. Supreme Court. Duke Power Co. v. Carolina Environmental Study Group, 438 U.S. 59 (1978).

ee. Pub.Law 100-408, 102 Stat. 1066. 


\section{LLW TRANSPORTATION RISK}

Radiological risks caused by LLW transportation are calculated estimates of radiological hazards that would result from a specified set of LLW shipments. A radiological hazard is a possibility of suffering harm (a) by fatalities from exposure to radiation or (b) from economic losses. LLW transportation radiological risks to drivers, the public, or LLW disposal facility workers can be calculated to determine potential impacts from various sets of LLW shipments. A radiological risk analysis requires a detailed description of a potential set of LLW shipments. For example, the following parameters describe sets of LLW shipments that may be potentially transported at different times and under different circumstances:

- The number of LLW shipments expected to be received at a LLW disposal facility during the operating lifetime of the facility

- The number of LLW shipments expected to be received at a LLW disposal facility during a given year

- The number of LLW shipments following a particular route

- The number of LLW shipments of a particular type of radioactive waste materials (e.g., combustible wastes, solidified wastes)

- The number of LLW shipments in a particular type of shipping package (strong, tight packages, Type A packages, or Type B packages)

- Any other estimate of future LLW shipments that can be described and related variables adequately quantified.

With a properly described set of assumptions regarding the LLW shipments of interest, the results of a LLW transportation radiological risk analysis can be used for several purposes. Decisionmakers and other groups can use the results to

- Estimate the potential health, economic, and environmental impacts expected from a proposed set of LLW shipments

- Compare changes to the conditions assumed for proposed set of LLW shipments to reduce radiological risks by implementing effective hazard controls or consequence mitigation measures

- Compare routes to and locations for sites for LLW disposal facilities

- ". . examine regulations to ensure continuing consistency with the goal of limiting radiological impact to a level that is as low as reasonably achievable ..."5

- Compare results to other risks accepted by modern society. 
The information below discusses how potential impacts of LLW transportation can be determined for sets of shipments and assumptions that may be of interest to States. The radiological risks can be estimated using a computer code called RADTRAN 4.0, developed by Sandia National Laboratories (SNL) for the U.S. Department of Energy (DOE). ${ }^{6}$ States may want to use this tool, which is made available without charge by the DOE. ${ }^{\text {? }}$

RADTRAN 4.0 is a risk analysis technique that calculates a radiological risk as a product of the probability of an event occurring and the expected radiological consequence of such an event. A radiological consequence is described in terms of injuries and fatalities or economic losses. Since determining radiological risk requires predicting probabilities of future events occurring, the degree of uncertainty varies with each predicted probability. Similarly, predicting consequences of complex events that affect human health involves forecasting a sequence of actions, each of which have some associated uncertainty.

As a product of two uncertain terms, estimates of radiological risk for LLW transportation also have uncertainty. Results calculated by RADTRAN are useful in providing approximate values for radiological consequences and risks. As with results from any sophisticated statistical analysis, caution is needed when applying results. Users need to fully understand inputs, default values, calculational approaches, and outputs.

Results predicted by RADTRAN are useful both as "absolute" values and for relative comparisons of results among alternatives. "Absolute" values of LLW transportation risk are conservative or bounding analyses to establish that Federal controls imposed on such shipments make them safe to drivers, the public, and LLW disposal facility workers. "Absolute" results also then help to establish the degree of harm relative to other activities accepted by modern society. The expected harm from LLW shipments can be compared to harm from cigarette smoking, driving a car, living in a city, and other hazardous activities.

Relative comparisons of LLW shipment radiological risks allow impacts of proposed resolutions for LLW transportation issues to be evaluated for whatever LLW shipments are of interest. The results obtained for different sets of input variables can show the effect of changes in assumptions regarding the shipments (such as changes to destination, routing, material forms, packaging, and other variables).

Two types of risk result from LLW shipments. One risk is vehicular accident risk, or nonradiological risk. This type of risk involves personal injury or financial loss from moving any material by vehicle. The other risk is radiological risk, or the possibility of exposure to radiation during LLW shipment loading, transport, and unloading, or from an accident during a LLW shipment.

The probability of a vehicular accident for LLW shipments is estimated from historical statistical data on highway accidents. The accident frequency data are used to represent the expected LLW shipments and to predict accidents per mile traveled. The prediction of the probability of a LLW shipment accident per mile should use the best information available to a State for highways, streets, and roads on a proposed route.

The nonradiological consequences in a LLW shipment accident can range from injuries to fatalities and economic loss of vehicles or property for those parties involved. RADTRAN has not 
been developed to predict nonradiological consequences of LLW shipment accidents. Commercial insurers of freight-moving companies would be best suited to estimate economic consequences for vehicular accidents without radiological consequences since insurance rates are set using such data. RADTRAN uses predictions of the frequency with which accidents with increasingly more severe consequences occur (increasing accident severity categories) to estimate when radiological consequences from LLW shipment accidents would be expected.

Radiological risk for LLW shipments is calculated in part by considering exposures to the amounts of radiation emitted from shipping packages containing LLW that are allowed under DOT regulations. Radiological risk also includes the potential for radiation exposures from releases of radioactive waste materials in an accident during transport.

Although only small amounts of radiation are allowed to be emitted from shipping packages for normal (incident-free) conditions of LLW transport, the overall population dose (radiation doses to drivers, the public, and LLW disposal facility workers) can be estimated from exposures to many persons per shipment and to many LLW shipments. In an accident, an external radiation dose rate from a damaged LLW shipping package may be higher than for normal conditions, and in severe accidents, release of radioactive waste materials may result in direct exposure to persons or intake of released radionuclides by persons.

\subsection{Estimating LLW Transportation Risks}

The RADTRAN 4.0 computer code can be used to estimate radiological risks for transport of all radioactive materials including LLW. The use of RADTRAN for this purpose started around 1977.8 Subsequent versions have improved the features and incorporated significant advances., 10, 6 The code addresses all modes of transport and so includes the capability to assess any LLW shipment. The following discussions focus on highway LLW shipments since the majority of LLW is sent to disposal facilities by this mode. LLW shipments by other modes can also be evaluated by the code if desired.

RADTRAN accounts for the steps that can occur in a LLW shipment and follows the progression of LLW materials from loading a LLW shipping package onto a vehicle, transport, additional handling if temporary storage or shipment consolidation is used, and unloading from the vehicle at the ultimate destination. This sequence of events results in occupational radiation exposures to both LLW shipment drivers and workers at LLW disposal facilities and in small radiation exposures to those members of the public present when a LLW shipment passes by.

The RADTRAN code is two separate modules used to calculate risks for normal (incident-free) transport and risks from accidents during transport. The module to calculate impacts from incidentfree transport includes four parts, called models: a material model, a transportation model, a population model, and a health effects model. The accident impacts module uses information from these four models plus two additional models: an accident severity and package release model and a meteorological dispersion model. An economic model is also available. The modules, models, and equations used by RADTRAN are discussed in detail in Reference 10. 


\subsubsection{Risk Estimate Results}

Results of RADTRAN 4.0 risk analyses are presented as estimates of the radiological impacts of both incident-free LLW shipments and potential accidents involving those shipments. Radiological impacts are radiation exposure doses to persons that can be converted to health effects and economic costs resulting from LLW accidents. Health effects include early morbidities, early fatalities, latent cancer fatalities, and genetic effects. Economic costs are in dollars that can be adjusted for inflation or particular potential accident consequence conditions and locations of interest.

In converting person-rem to health effects, RADTRAN uses a model developed for the NRC's Reactor Safety Study. ${ }^{11}$ Alternately, a user may choose to obtain RADTRAN's population dose (person-rem) results and convert doses to health impacts using more recently developed models of the effects of low-level radiation exposures on humans. ${ }^{12,13}$

4.1.1.1 Incident-Free Results. The population doses (person-rem) for incident-free transport consist of the total amount of whole-body doses to radiation for persons with a potential to be exposed due to a specific set of LLW shipments. The various subgroups or populations of persons with a potential to be exposed to radiation as a result of highway LLW shipments include

- Crew-Persons on a van, small truck, or combination tractor-trailer

- Handlers-Persons at a loading, unloading, storage warehouse, or LLW shipment consolidation facility

- $\quad$ Off-link (surrounding) population-Persons within a certain distance of a LLW shipping package off the edge of either side of a highway, road, or street (i.e., in fields, in parking lots, on sidewalks, in buildings)

- On-link (people in vehicles) population-Persons traveling in the same direction or the opposite direction on the same highway, road, or street

- Population at stops-Persons near a LLW shipment when a vehicle stops for refueling, meals, and crew changes

- $\quad$ Storage and warehouse personnel-Persons near a LLW package during storage at a warehouse or shipment consolidation facility.

RADTRAN provides population dose (person-rem) estimates for each applicable population subgroup for all LLW shipments specified by the user for the analysis. RADTRAN also calculates the total incident-free doses as the sum of the doses for persons exposed in the above population subgroups (not all subgroups need be applicable to a specified set of LLW shipments). Persons in each of the affected populations would each be estimated to receive a small fraction of the population dose from one of the LLW shipments. Although different persons would most likely be present along a route for each LLW shipment, RADTRAN does allow the user to consider a maximum total dose to an individual potentially exposed to all shipments. This maximum individual in-transit dose is calculated for a person living beside a road on the route and would be present for each shipment considered in the analysis. 
Also, RADTRAN identifies occupational doses received by crews of exclusive-use LLW shipments, handlers at loading and unloading facilities, and storage and warehouse personnel. These occupational doses are the sum from all shipments in a campaign and are not necessarily to one particular crew working on the shipments. Occupational doses are of separate interest since limits apply to annual exposures for workers. The concept of reducing exposures to workers to as low as reasonably achievable (ALARA) should be considered in evaluating the exposures from RADTRAN estimated for drivers and workers. For example, if shielding is added to the cab of a tractor-trailer to reduce dose rates to crews even if dose rates would be below the regulatory limit of 2 millirem per hour, inputs to RADTRAN would need adjustment to allow RADTRAN to predict lower and more representative estimates of crew exposures for a set of LLW shipments.

4.1.1.2 Accident-Free Results. Besides incident-free radiation exposures, RADTRAN calculates impacts due to the possibility of accidents during LLW shipments. Results for accidents include the expected number of accidents, early and long-term radiological consequences, and economic consequences.

The accident summary results for a specified set of LLW shipments analyzed by RADTRAN are presented based on both potential locations of accidents and estimated severities of the accidents. The number of accidents in each category of accident severity is determined along a route for each population density zone (rural, suburban, or urban population zones). In general, the more severe an accident, the less likely such an accident will occur but the greater the potential consequences. If more than one mode of transport would be involved in a set of shipments, (for example, a combined rail and highway route), results would be presented for each mode.

Three types of expected consequences are calculated by RADTRAN for truck accidents for each accident severity category in each population zone. Totals (summed over all specified shipments) are provided for:

- Early fatality consequences-Number of persons fatally injured within one year from person-rem received from significant sources of external radiation (principally LLW released from severely damaged shipping packages to which persons are directly exposed) plus person-rem due to internal radiation exposures from airborne LLW released as aerosol that is subsequently inhaled by persons near accidents

- Long-term radiological consequences-Person-rem doses for a 50-year period to persons exposed to external and internal radiation doses resulting from LLW shipment accidents

- Economic consequences-Costs for LLW shipment accidents including emergency response, evacuation, cleanup, and long-term loss of use of contaminated land.

These consequences for the specified LLW shipments are used by RADTRAN with the estimate of the number of expected accidents for the shipments to determine the expected value of population risk for the shipments. This risk is presented as total person-rem for the specified shipments, as the risk per nuclide in the LLW, and as the risk per exposure pathway. The radionuclides in the LLW are specified by the user in describing the shipments. For LLW shipments with mixed fission products, a few of the radionuclides contribute the majority of the radiological consequences. The radiation 
exposures for the following pathways are calculated by RADTRAN for each radionuclide released in LLW shipment accidents:

- Groundshine-The dose to persons near accidents from exposure to radiation from radionuclides deposited on the ground

- Inhaled-The dose to organs in persons near accidents from exposure to internal radiation from radionuclides dispersed into the air, inhaled, and distributed throughout a body to various organs

- Resuspended-The dose to persons near accident sites from exposure to internal radiation from radionuclides originally deposited on the ground that are subsequently resuspended in the air due to wind or traffic and then inhaled

- Cloudshine-The dose to persons near accidents from exposure to radiation from radionuclides suspended in a cloud in which a person is immersed

- Ingestion-The dose to persons in the general population away from accident sites from exposure to internal radiation from ingestion of food supplies that are contaminated with radionuclides (only for accidents occurring in agricultural areas).

In addition to the results noted above, intermediate results calculated by RADTRAN are stored for each run and are available if needed.

\subsubsection{Risk Calculations}

The calculations performed by RADTRAN to determine the results noted above are extensive. Users of RADTRAN need to obtain and review the available documentation., ${ }^{6}$ Only by understanding the calculational methodologies can users ensure that the results are interpreted correctly and that suitable input values are provided for each variable. RADTRAN has been designed to be user friendly, but default values that are available for many of the variables should be reviewed and determined to be applicable so that RADTRAN results correctly predict the risks of a set of LLW shipments of interest.

\subsubsection{Risk Analysis Input Values}

RADTRAN 4 is run by creating an input file describing parameters important for risk analysis of a specified set of LLW shipments. Results are presented for that set of shipments. Users can take advantage of the flexibility built into RADTRAN to create multiple input files that are similar with only one input (or a few) changed and so examine the effects of small changes between runs.

Because of the complexity of the RADTRAN calculations, not all the values that enter into a LLW shipment risk analysis can be adequately described below. Reference 6 is a detailed guide for users and describes the full extent of the inputs needed, defaults available, and calculational options. Most of the default values used in the calculations can be changed by a user if warranted. Certain input values must be entered by a user. Guidance is available for creating input files for any LLW shipments of interest. 
Basic to performing an analysis is a thorough understanding of the set of LLW shipments of interest. Many aspects of the shipping package, LLW payload, route, and shipment logistics must be known or estimates determined to fully specify the information needed to make a RADTRAN input file.

- Mode-The transportation mode must be specified. Choices for highway transport are a combination truck, a passenger van (small truck), or a cargo van/delivery truck used as a secondary mode with a combination truck. Exclusive use shipments may also be specified.

- Number of shipments-The number can be per year, per project, or all shipments expected to be received at a LLW disposal facility. This value depends on the LLW shipments of interest to a State and how to best describe them for purposes of risk analysis.

- Number of shipping packages per conveyance-The number of packages of LLW per vehicle must be at least one but may be more.

- $\quad$ Package size-The size of the shipping package for each type of LLW analyzed must be specified to allow the calculation of doses to persons near a package along a route. Also, the size determines what type of handling occurs at loading and unloading locations (by hand, by forklift, or by crane). The type of handling in turn determines the number of workers needed and their proximity to a package during handling. Users should review the calculational model and necessary input values to ensure handling at a LLW disposal facility is appropriately modeled for expected operations.

- Dose rate-The package dose rate at one meter in millirem per hour. Single package LLW shipments may use the Transport Index (TI) for a package directly as the input value. Multiple package and exclusive-use shipments may require calculations to determine an appropriate input value depending on geometries of packages on a vehicle.

- Nuclides-The curies per package for each nuclide present must be specified (at a minimum, curie estimates are needed for major contributors to radiological consequences). Many nuclides important to LLW shipments have nuclide-specific information available as data for use in RADTRAN that can be accessed by specifying the nuclide's name. This health effects-related information may be changed by a user. For nuclides not available in RADTRAN, a user specifies half-life, photon energy, cloudshine dose factor, 50-year committed dose equivalent for inhalation and ingestion, food and soil transfer factors, deposition velocity of aerosol particles, lung type for early effects calculations, and oneyear lung and marrow doses for inhalation.

- Physical chemical form-The nuclides in a package are separated into physical chemical groups that represent how each nuclide responds after release in accident conditions (e.g., gases, volatiles, oxides).

Accident severity categories-Up to twenty accident severity categories may be assigned although six or eight are more commonly used. For each severity category, users specify the conditional probability that an accident of that severity would occur for a rural, suburban, and urban population zone. That is, in each zone, a user specifies the fraction 
of accidents that would occur in each accident severity category such that the sum of the fractions should add to approximately 1.0.

- Release, aerosol, and respirable aerosol fractions-Each physical chemical group is assigned values that describe what fraction is released, transported, and inhaled in each accident severity category. Although default values for release fractions are not available in RADTRAN, values used previously in earlier studies can be considered and input by a user. Both aerosol and respirable aerosol fractions have default values categorized by material dispersibility that accounts for how easily radionuclides contaminating such materials would be transported by air. Material dispersibility categories include loose chunks, large powder, small powder (or nonvolatile liquids), spent fuel particulates, volatile solids, liquids, gases, flammables, and immobile materials (nondispersible).

- Distance-The total distance for the entire route can be specified, or a route may be broken into parts called links. A unit distance ( 1 kilometer) can also be used to obtain unit risk factors for each population density zone. A unit risk factor multiplied by the number of kilometers in a zone on a route provides an easy means to analyze several alternate routes.

- Incident-free operational details-Many values are needed to determine doses to workers, crews, and the public for normal or routine LLW shipments. These values include:

- Fraction of travel in rural, suburban, and urban population zones

- Travel velocity in each population zone

- Number of persons in the crew

- $\quad$ Average distance between LLW package and crew

- Number of times a LLW package is handled

- Average and minimum amount of time a shipment is stopped along route

- $\quad$ Number of persons exposed while a shipment is stopped

- Average distance between LLW package and persons while a shipment is stopped

- Number of persons per vehicle on each link

- Fraction of urban travel that is on city streets or during rush hour traffic

- Number of vehicles per hour going in one direction in each population zone

- $\quad$ Shielding factors to account for no shielding between LLW packages and persons along route, frame dwellings in a rural population zone, masonry construction in a suburban zone, or concrete in an urban zone 
- Pedestrian density as a ratio of the urban population zone density to account for unshielded persons in an urban zone.

- Accident rates for each population density zone-Default values are provided based on historical data representing national averages. Users may specify other values based on State or route-specific information. Historical data on LLW shipment accident rates is not readily available. For accidents involving releases of LLW, consideration should be given to which measure of accident frequency would provide the best indicator for LLW shipments. Possible rates include hazardous material truck driver fatality rate, general truck driver fatality rate, hazardous material truck fatal accident rate, general truck fatal accident rate, general vehicle traffic fatality rate, general traffic accident rate, and accident rate predictive models. Rates of fatalities are suggested because such accidents imply severe damage to the vehicle and potentially to LLW packages. Similarly, hazardous materials shipments would be most like the LLW shipments of interest assuming drivers of such shipments are better trained or otherwise achieve lower accident rates than average nonhazardous commodity drivers. Historical data on too narrowly defined a measure may not be valid due to lack of a sufficient amount of statistical data.

- Accident dispersion details-Many values are needed to determine how LLW released in an accident is spread downwind and causes health or economic impacts. The needed information includes:

- Atmospheric stability classes and relative frequencies

- Amount of area contaminated downwind of an accident scene; areas are defined by nested ellipses that are concentric

- $\quad$ Breathing rate for persons exposed to released LLW

- Building dose factor to account for the reduction in dose to persons inside of a building in urban population zones rather than outside; this accounts for air filtration by ventilation systems in buildings

- Fraction of rural land that is being farmed and has food supplies that may become contaminated

- Costs for immediate response to an accident for each accident severity category, including law enforcement, emergency response, and restoration of the highway, road, or street

- Costs for decontamination of land to remove LLW released in an accident to a specified cleanup criteria

- Economic factor to adjust 1980 default values for immediate accident response and site decontamination costs to present or future dollars. 
As noted at the introduction to this listing of necessary input values, a considerable amount of information is needed to perform a transportation risk analysis for a specified set of LLW shipments. RADTRAN provides many values as defaults to assist users, and SNL can supply suggested values for parameters not supplied directly as defaults. By not providing default values, users are forced to make conscious decisions regarding input values and understand the significance of their choices. Suggested values for parameters without defaults are available from published reports and input files for previous analyses performed by RADTRAN. For example, LSA wastes transported to LLW disposal sites have been studied and input files are available on TRANSNET. 7,15

Once a user has created an initial input file or has decided to modify an existing file that is available through TRANSNET, new files are easily created to perform comparative risk analyses. The effect of a change of a single variable can be determined by comparison runs. Changes are made through a menu-driven set of commands. Selection of a menu item leads a user to subsequent screens that permit entering or revising values and other calculational options.

\subsection{NUREG-0170 Results of Using RADTRAN}

Use of RADTRAN for risk analysis of the transportation of radioactive materials dates back to 1977 and the issuance of NUREG-0170, Final Environmental Statement on the Transportation of Radioactive Material by Air and Other Modes (Reference 5). NUREG-0170 was issued pursuant to the National Environmental Policy Act (NEPA) of 1969 and an NRC review of regulations pertaining to nuclear materials originally promulgated by its predecessor organization, the Atomic Energy Commission (AEC).

NUREG-0170 concluded that, based on the amounts of radioactive material that were estimated to have been transported in 1975 and for projections to 1985 ,

The average radiation dose to the population at risk from normal transportation is a small fraction of the limits recommended for members of the general public from all sources of radiation other than natural and medical sources ... and is a small fraction of natural background dose...

The radiological risk from accidents in transportation is small, amounting to about one-half percent of the normal transportation risk on an annual basis ... (Reference 5, p. vii)

These results are cited to place the radiological risks of transportation of LLW into perspective, since LLW shipments are but a fraction of all radioactive material shipments. Further, for the opening of new LLW disposal facilities, the risks from LLW shipments in any State or compact region will be but a fraction of total risk for all LLW shipments.

States should continue to cite the overall conclusion of NUREG-0170, which determined that annual radiological risk from transportation of all radioactive materials would have small impacts on persons and the environment. However, readers are cautioned that before citing numerical results from NUREG-0170 as discussed below, they should read the report and become informed on the overall purpose, approach, assumptions, calculational methods, and published results to prevent using isolated values out of their intended context. 


\subsubsection{Incident-Free and Accident Risks}

To summarize a few of the main assumptions in NUREG-0170, all radioactive materials were represented by an estimate of the total number of radioactive material shipments in 1975 and projections to the year 1985. The total for all radioactive materials shipments was obtained by summing projections for five types of radioactive material shipments. The shipment types for which summary radiological impacts are presented included limited quantity, medical, industrial, fuel cycle, and waste shipments. For each shipment type, the following information was presented:

- Number of packages shipped per year

- Amount of curies shipped per year

- TI shipped per year

- Kilometers traveled per year

- Number of latent cancer fatalities (LCFs) per year for normal (incident-free) shipments

- Percentage of the total LCFs for normal shipments

- Number of LCFs per year for accident conditions

- Percentage of the total LCFs for accident conditions.

NUREG-0170 presents results for a shipment type designated waste. This shipment type should represent all radioactive wastes sent to commercial LLW disposal facilities. Waste type of shipments are assumed to be LLW that are generated from medical, industrial, or fuel cycle activities and is separated from these activities when the material is shipped as waste. Given that the shipment type waste is for LLW, Table 1 shows shipment summary and risk results for the total or all radioactive material (RAM) shipments and for waste (or LLW) shipments as presented in Table 1-2 of NUREG-0170.

NUREG-0170 results clearly show the low radiological risks for all radioactive material shipments and the even lower risks for waste (LLW) shipments. Even if LLW is not completely the same as NUREG-0170's shipment type waste, the differences cannot significantly affect the conclusion.

NUREG-0170 results still support NRC's current regulations and are often quoted when estimates of the risks of modern-day radioactive material transportation are needed. The greater health-impacts significance of incident-free transport compared to accidents during transport is readily apparent from the large differences in risks of LCFs for normal versus accident conditions of transport. The two to four orders of magnitude differences are likely even greater than the reported values since accident results reported in NUREG-0170 have a high degree of conservatism. Too conservative assumptions may have been used for package release fractions, particle size, fraction of released material becoming airborne, and areas affected by releases. The conservatism was acceptable for purposes of NUREG-0170 since the basic conclusions were not affected (Reference 3, p. ix). 
Table 1. Shipment summary and risks results.

\begin{tabular}{lccccc}
\hline \multicolumn{1}{c}{\begin{tabular}{c}
1975 \\
\multicolumn{1}{c}{ Shipment } \\
type
\end{tabular}} & $\begin{array}{c}\text { Packages } \\
\text { per year }\end{array}$ & $\begin{array}{c}\text { Curies } \\
\text { per year }\end{array}$ & $\begin{array}{c}\text { Kilometers } \\
\text { per year }\end{array}$ & $\begin{array}{c}\text { LCF (normal) } \\
\text { per year }\end{array}$ & $\begin{array}{c}\text { LCF (accident) } \\
\text { per year }\end{array}$ \\
\hline $\begin{array}{l}\text { Total } \\
\text { (all RAM) }\end{array}$ & $2.2 \mathrm{E}+5$ & $5.6 \mathrm{E}+8$ & $2.6 \mathrm{E}+9$ & 1.2 & $4.7 \mathrm{E}-3$ \\
$\begin{array}{l}\text { Waste } \\
\text { (LLW) }\end{array}$ & $1.5 \mathrm{E}+5$ & $2.7 \mathrm{E}+5$ & $3.2 \mathrm{E}+6$ & 0.2 & $6.2 \mathrm{E}-4$ \\
& & & & & \\
\hline $\begin{array}{l}\text { Shipment } \\
\text { type }\end{array}$ & $\begin{array}{c}\text { Packages } \\
\text { per year }\end{array}$ & $\begin{array}{c}\text { Curies } \\
\text { per year }\end{array}$ & $\begin{array}{c}\text { Kilometers } \\
\text { per year }\end{array}$ & $\begin{array}{c}\text { LCF (normal) } \\
\text { per year }\end{array}$ & $\begin{array}{c}\text { LCF (accident) } \\
\text { per year }\end{array}$ \\
\hline $\begin{array}{l}\text { Total } \\
\text { (all RAM) }\end{array}$ & $5.6 \mathrm{E}+6$ & $8.5 \mathrm{E}+6$ & $6.0 \mathrm{E}+9$ & 3.1 & $1.7 \mathrm{E}-2$ \\
$\begin{array}{l}\text { Waste } \\
\text { (LLW) }\end{array}$ & $6.3 \mathrm{E}+5$ & $1.1 \mathrm{E}+6$ & $1.3 \mathrm{E}+7$ & 0.8 & $2.5 \mathrm{E}-3$ \\
\hline
\end{tabular}

Comparisons of projections to 1985 from NUREG-0170 are discussed in Section 4.3.

\subsubsection{Risks to Drivers, the Public, and Disposal Facility Workers}

NUREG-0170's incident-free results consider radiation exposure doses to two types of population subgroups: radiation workers and the public. Many LLW shipment drivers are radiation workers as are workers at LLW disposal facilities. The public includes persons on-link, off-link, and at stops (see Section 4.1.1.1).

Tables 4-16 and 4-18 in NUREG-0170 provide estimates of incident-free doses to drivers (crews) for waste shipments. Table 2 presents estimated annual doses for 1975 and 1985 waste shipments in strong-tight, Type A, and Type B shipping packages. Doses to crews are shown to be higher for waste shipments in Type A packages in Table 2 because there are both more shipments of materials in Type A packages than in LSA or Type B packages and longer distances per shipment.

The total incident-free doses for all shipments estimated as truck and van transports were also reported. The truck crew dose was estimated to be 2,580 person-rem for 1975 truck shipments with a maximum individual dose of 870 millirem for spent fuel shipments by truck. A maximum individual dose for a crew member was not provided for only waste shipments.

Incident-free exposures for handlers for waste shipment types that would represent workers at LLW disposal facilities were not provided in NUREG-0170. Such workers are known to be exposed to the highest dose rates of any population subgroup since these workers come physically the closest to loaded shipping packages during handling (loading and unloading) operations. However, occupational doses may be small since each package is handled for a relatively short amount of time. 
Table 2. Estimated annual incident-free doses to crews for waste shipments.

\begin{tabular}{ccccc}
\hline \multicolumn{5}{c}{ Person rem/year } \\
\hline Year & Strong, tight & Type A & Type B & Total \\
\hline 1975 & 17.4 & 139.0 & .0565 & 157 \\
1985 & 71.9 & 574.0 & 2.330 & 648 \\
\hline
\end{tabular}

NUREG-0170 reported a total annual handler dose of 1,740 person-rem for all standard shipments and a total of 54 person-rem per year to handlers of large casks (irradiated fuel and irradiator sources casks). A maximum individual dose for a handler was not provided for only waste shipments.

Both drivers and workers at LLW disposal facilities have the highest risks for individual doses from LLW shipments. These groups of radiation workers should be considered under radiation protection safety programs to ensure doses are ALARA. Drivers of LLW shipments to a commercial LLW disposal facility in South Carolina during the years 1980 to 1982 were reported by ChemNuclear Systems, Inc. to have annual radiation doses of 114 mrem/year. ${ }^{16}$

NUREG-0170 results for incident-free shipment doses for the public include the surrounding population either off-link, on-link, or at stops. Tables 4-16 and 4-18 in NUREG-1070 provide estimates of doses to each subgroup for waste shipments. Table 3 estimates the annual incident-free doses for 1975 and 1985 waste shipments in strong-tight, Type A, and Type B shipping packages.

Table 3 shows that in NUREG 0170 there is a projected increase in the person-rem/year doses from the year 1975 to the year 1985 because of expected increases in the numbers of shipments over that decade.

Risks to drivers, the public, and workers at LLW disposal facilities from accidents involving LLW shipments are not presented in a table since they are not separated into risks for the subgroups. Only a single population that encompasses all persons near an accident site is considered in the calculations as shown in Table 1 . As noted previously, radiological risks from accidents are much lower than for incident-free transportation.

\subsubsection{Economic Consequences}

Economic consequences from contamination due to a wide range of radioactive material transportation accidents were also addressed in NUREG-0170. Results are considered only order-ofmagnitude accuracy since many assumptions are needed to make an estimate. Four land-use situations were evaluated: rural (undeveloped), farmland/dairyland, suburban, and urban. Each was analyzed for a range of curies released in an accident and for both short-lived and long-lived isotopes, thus enveloping LLW transportation accidents. The estimated decontamination costs ranged from hundreds of dollars up to a billion dollars. 
Table 3. Estimated annual incident-free doses to the public for waste shipments.

\begin{tabular}{clcccc}
\hline \multicolumn{6}{c}{ Person-rem/year } \\
\hline Year & Group & Strong, tight & Type A & Type B & Total \\
\hline 1975 & & & & & \\
& Off-link & 3.45 & 254.0 & 0.357 & 258 \\
& On-link & 1.70 & 125.0 & 0.176 & 127 \\
& Stops & 12.60 & 746.0 & 1.580 & 760 \\
& Total & 17.75 & $1,125.0$ & 2.113 & 1,145 \\
& & & & & \\
& Off-link & 14.30 & $1,050.0$ & 1.470 & 1,066 \\
& On-link & 7.04 & 516.0 & 0.726 & 524 \\
& Stops & 52.00 & $3,080.0$ & 6.510 & 3,139 \\
& Total & 73.34 & $4,646.0$ & 8.706 & 4,728 \\
\hline
\end{tabular}

\subsubsection{Worst-Case Accident Results}

NUREG-0170 considered consequences from severe accidents in very high population density urban areas separately. Accidents in New York, Chicago, and similar large cities could have consequences more serious than others presented in the report. Table 5-12 in NUREG-0170 shows integrated population doses and expected LCFs from certain accidents in the highest accident-severity category in high-density urban areas. Standard shipments of polonium-210, plutonium, cobalt-60, and spent fuel were modeled. Up to a million person-rem and $147 \mathrm{LCFs}$ were calculated with probabilities of 1 in 50 million per year and orders-of-magnitude less. The worst consequences were the least probable with a 1 in 100 billion per year chance of occurring.

\subsection{Applicability of NUREG-0170 Results to Current LLW Shipments}

The conclusions from NUREG-0170 are as valid today as when the report was issued. All RAM shipments taken as a group were then, and are now, quite low by any measure of comparison. LLW shipment risks, as a small fraction of the total RAM transportation risks, are likewise very low. Conservative assumptions and calculational methods developed and used in NUREG-0170 are still appropriate and embodied in the current version of RADTRAN 4. Except for minor differences, using the input values from NUREG-0170 in a RADTRAN 4 calculation results in the same basic numerical results and exactly the same conclusions.

When States encounter circumstances that require more current or accurate estimates of the numerical results originally presented in NUREG-0170, inputs used in NUREG-0170 may be out of date for certain types of shipments. When NUREG-0170 was written in the mid-1970s, substantial numbers of spent fuel shipments were predicted to be occurring by the mid-1980s. Also, plutonium 
recycling was expected to be a part of the nuclear fuel cycle. Such outdated predictions and assumptions can make the NUREG-0170 results too conservative for direct use today. At the same time, NUREG-0170 results can be of concern to the public because the assumptions do not reflect use of the best information currently available even though most refinements would tend to remove extreme conservatism, better predict actual conditions, and lower risk estimates.

Also, since LLW shipments are not clearly tied to the shipment type waste and not all intermediate results of calculations of potential interest were presented, NUREG-0170's numerical results may be inadequate for meaningful application by States and compact regions developing LLW disposal facilities. Again, general conclusions apply to LLW shipments, but numerical results require thorough understanding of inputs and assumptions before judicious use of actual values.

The applicability of the numerical results in NUREG-0170 is a subject of research. ${ }^{17}$ Given the availability of RADTRAN as a tool to perform current LLW transportation risk analyses, States and compact regions may want to take advantage of this readily accessible method to determine risks for LLW shipments of interest for their own circumstances. States will find a major difference between RADTRAN 4 and earlier versions (and analyses performed with them) in that RADTRAN 4 provides an ability to do route-specific analysis.

\subsection{RADTRAN Results for LLW Shipments}

Since NUREG-0170 was issued, additional work using RADTRAN to estimate risks from transportation of RAM has been documented. Of interest to States and compact regions are reports addressing LLW transportation.

A summary report presents the unit-risk factor method of estimating risks of LLW shipments. ${ }^{18}$ Unit-risk factors are the risks per kilometer of travel in each type of population density zone. Users evaluate proposed routes for LLW shipments and determine the number of kilometers in each zone. These distance estimates times the unit-risk factors provide an estimate of risk for each population zone. Addition of the risks for the rural, suburban, and urban zones on a route is an estimate of a route's risks.

The unit-risk methodology was used in a 1983 draft environmental assessment of the transportation of RAM to and from U.S. nuclear power plants. ${ }^{19}$ The assessment predicted incidentfree and accident risks for 1985 and 1990 (then future years). LLW shipments are included and were determined to dominate annual risks from RAM shipments to and from nuclear power plants. This is expected since there are more LLW shipments than fresh and spent fuel shipments.

A report on the radiological impacts of transportation in the nuclear fuel cycle ${ }^{20}$ evaluates all shipments of RAM needed to operate a light water reactor for a year. Incident-free exposures are in general agreement with NUREG-0170. Estimates of risks from LLW shipments are included.

A subset of LLW shipments from reactors is addressed in a report on the potential risks from gamma-emitting LSA waste (Reference 15). Spent ion-exchange resins with high specific activity levels for LSA wastes were considered in an assessment of the quantity of radionuclides that can be contained in a single LSA waste shipment. Results were comparable to NUREG-0170 values. 
Risks from LLW shipment accidents were evaluated for the State of Oregon. ${ }^{21}$ As part of an evaluation of risks for all RAM shipments in Oregon, LLW shipments were found to have a radiological risk of less than $1 \times 10^{-5} \mathrm{LCF}$ per year. This value was a significant contribution to the overall level of risk from all RAM shipments because LLW shipments travel a large number of vehicle miles to the Richland commercial disposal site in Washington. A total risk of $1.2 \times 10^{-5} \mathrm{LCF}$ per year was predicted for 1989 levels of RAM transportation and compared to an estimate of 1.22 non-radiological fatalities resulting from the 750,000 RAM shipment miles per year in the State.

\subsection{More on Transportation Risk Analysis Methodologies}

While RADTRAN has been used extensively and is accessible to States and compact regions, other methodologies for performing transportation risk analyses are available. ${ }^{22}$

Federal regulations in Code of Federal Regulations (CFR) 49 CFR 177.825 identify a set of risk-based guidelines for selecting preferred highway routes for shipments of highway route controlled quantities of RAM. ${ }^{23}$ The TRANSNET system at SNL is available to assist in such evaluations (Reference 7). A model on TRANSNET known as StateGEN/StateNET assesses impacts of State and local data on highway routing choices. The model permits the input of data into RADTRAN.

Other models on TRANSNET include TRANSIT and TRANSIS. The TRANSIT model assists in siting waste facilities by evaluating transportation mileage, costs, risks, and fleet requirements for shipments to potential sites. TRANSIS is a summary of historical accident/incident data on hazardous materials transportation.

\subsection{Example of a State Risk Assessment}

An environmental study was conducted for the Martinsville Alternative Site in Clark County, Illinois, in 1990 and among the many aspects of the study, a risk assessment on transportation of LLW to the site was performed. ${ }^{24}$ One of the objectives of the transportation study was to conduct a preliminary risk assessment and to assess the environmental effects of project-related transportation.

The preliminary risk assessment was performed to identify radiological risks associated with transporting LLW to the Martinsville Alternative Site. The radiological risk was evaluated as the risk of human exposure to radiation from LLW shipments during normal transport and risk from exposure to radiation from packages damaged during transportation accidents. The following analysis is based on results obtained from reports that used the radiological risk assessment model RADTRAN III.

The following excerpt is taken from an environmental study performed for Clark County, Illinois, by Battelle in 1990:

The preliminary risk assessment assumes that 856 shipments involving a total of 230,633 cubic feet of waste will be sent to the Illinois LLW disposal facility each year. Of these, 791 will be from nuclear power plants and 65 will be from other sources. Table 4, which includes data for Kentucky sources as well as Illinois sources, summarizes numbers of shipments, waste volume, and interstate and noninterstate shipment miles from each waste generator expected to use the Illinois LLW disposal facility. 
In addition to the estimated shipment miles and volumes presented in Table 4, the radiological risk assessment was based on data from two SNL reports. ${ }^{15,19}$ Analysis of this data has determined that the total annual nonoccupational exposure for the entire route from all generators to the Martinsville Alternative Site would be from 8-30 person-rems. Total annual occupational exposure to the crews of the transport vehicles would be an additional 2-11 personrems. Total annual radiological risk from accidents is estimated to range from 1-11 person-rems.

The maximum individual exposure would be to an individual along a route segment who was exposed to every one of the 856 shipments. Of these shipments, 791 were projected to have an external radiation dose rate at 2 meters from the transport vehicle. Of the estimated annual LLW shipments to Clark County, Illinois, 65 were projected to have essentially no external radiation level. The maximum individual annual exposure was calculated on the basis of the following assumptions:

- Total maximum individual nonoccupational annual exposure is based on a person 30 meters from all 791 shipments passing by at a speed of 15 miles per hour

- Waste package radiation levels are no greater than 10 millirem per hour, the Federal limit at 2 meters from the LLW vehicle.

The maximum individual annual exposure is 2.5 millirem per year. By comparison, the average annual exposure to an individual in Illinois from naturally-occurring sources of radiation is about 300 millirem per year. About 200 millirem per year of the 300 millirem is from the inhalation of radon. 
Table 4. Estimated annual LLW shipments to Clark County, Illinois.

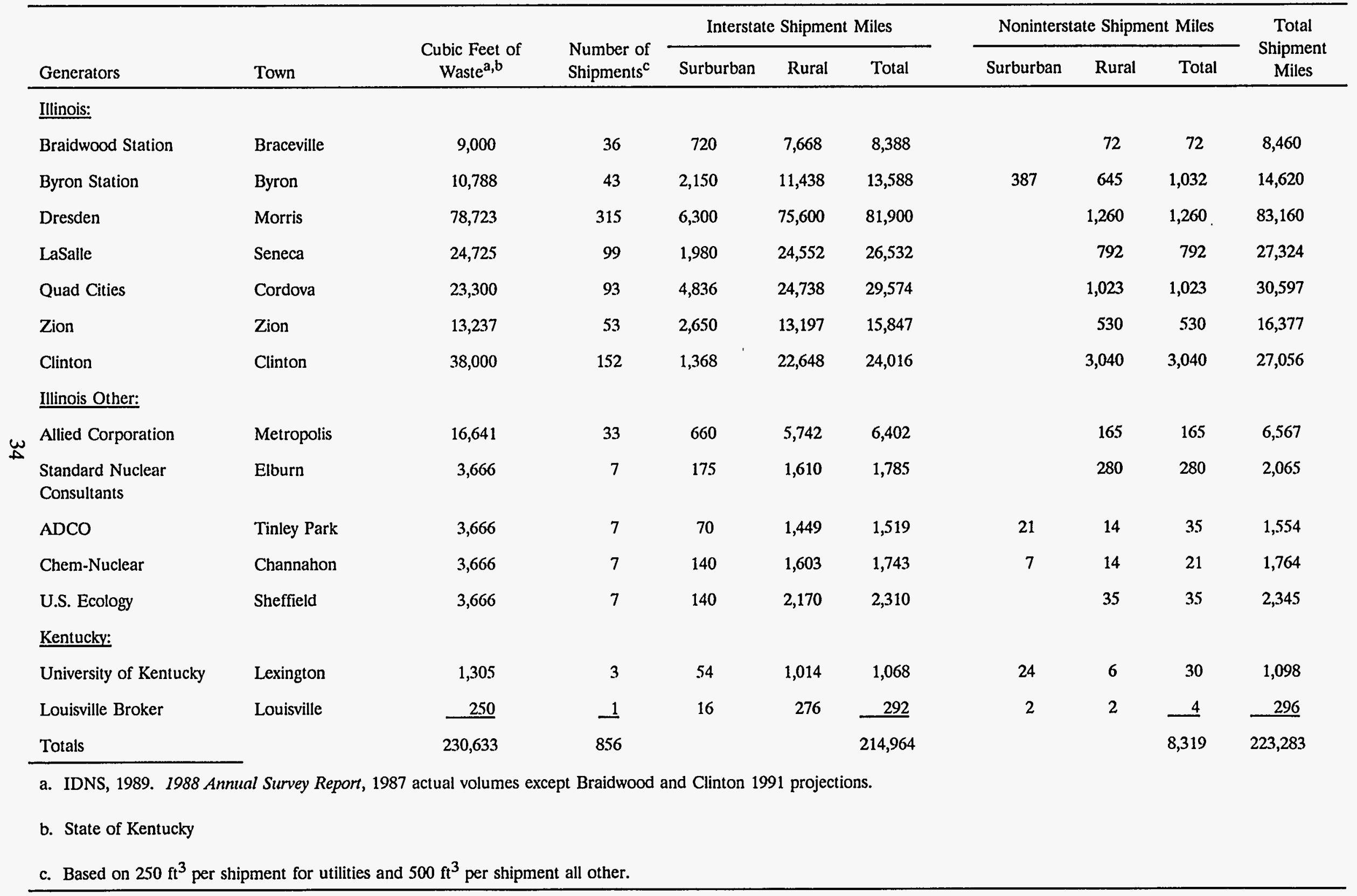




\section{LLW SHIPMENT ACCIDENTS}

\subsection{Transportation of Commercial Low-Level Radioactive Waste}

There are about 500 billion shipments of all kinds of commodities transported each year in the United States. About one in $\mathbf{5 0 0 0}$ of all shipments transported are hazardous materials shipments. About one in 50 of those are radioactive materials shipments. ${ }^{25}$ That is, there are about 2 million shipments of radioactive materials per year in the United States. ${ }^{26,27}$ In the years $1986-1990$, there was an average of about 11,062 shipments of LLW per year from all the States to the three currently operating disposal facilities-Barnwell, S.C.; Beatty, NV; and Richland, WA. ${ }^{3}$ Figure 2 shows a comparison of all shipments of all commodities per year to the number of hazardous and radioactive materials shipments per year. ${ }^{25}$

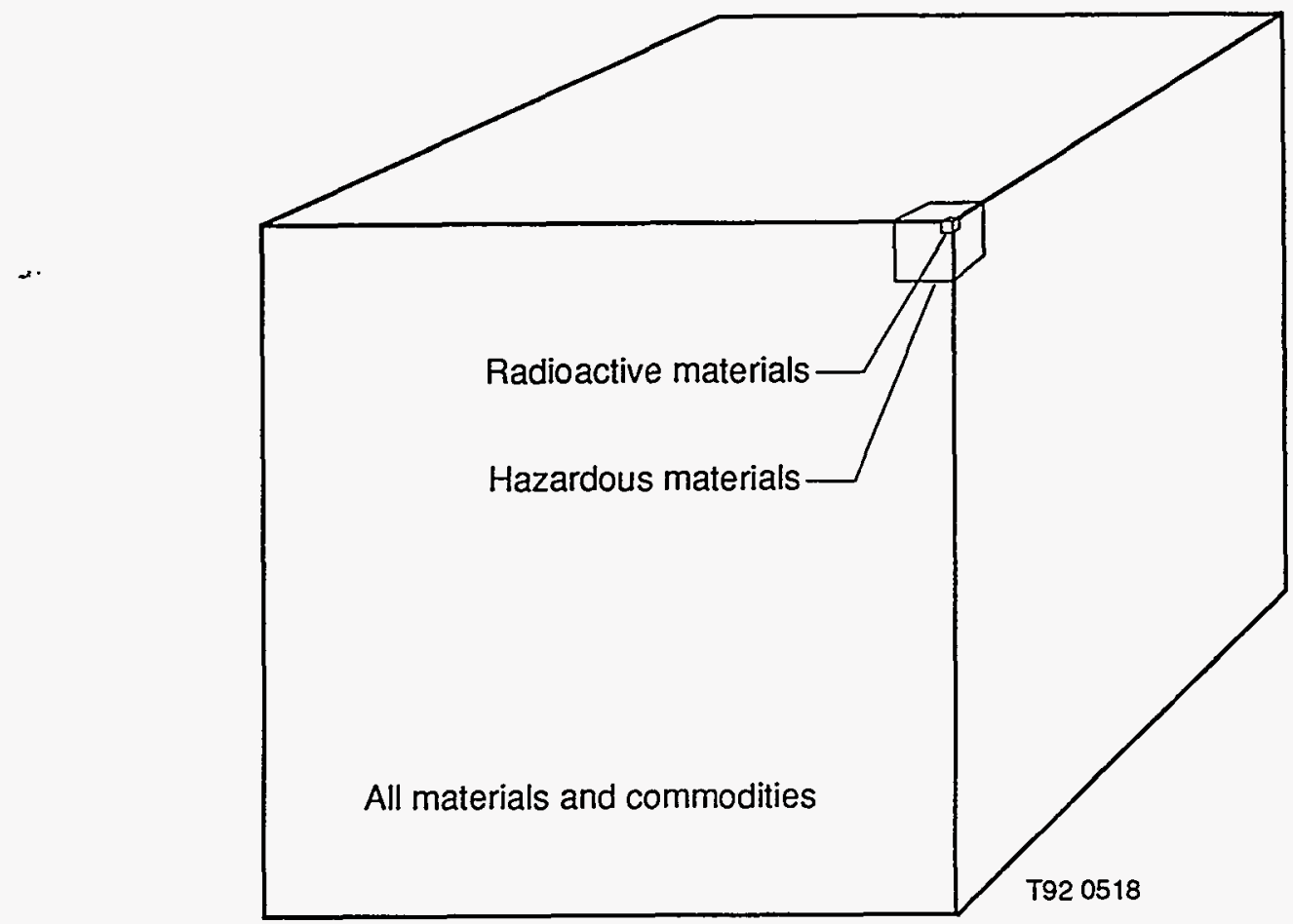

Figure 2. Comparison of all shipments of all commodities to number of shipments of hazardous and radioactive materials shipments in the United States each year. 
The Radioactive Material Incident Report (RMIR) ${ }^{\mathrm{ff}}$ data base was used as the source for most of the information compiled in this report. This data base, accessed through Sandia National Laboratories-Albuquerque, New Mexico, contains information on transportation-related accidents and incidents involving radioactive materials, including LLW. The data base, which covers the period from 1971 through the present, was developed to support research and development efforts of the DOE. The data base was designed primarily to record information reported on DOT Form 5800 (Hazardous Materials Incident Report), used to document transportation incidents. Entries into the data base meet both NRC and DOT regulatory requirements for notification of an incident. Three kinds of reported events are classified in the RMIR and are defined as follows (Reference 26):

- Incidents: Actual or suspected release of radioactive material or surface contamination exceeding regulatory requirements on either the package or transport vehicle

- Transportation accidents: A transport event ranging from a minor accident to a major collision that involves the vehicle transporting the radioactive material

- Handling Accidents: Damage to a shipping container during loading, unloading operations (e.g., a forklift puncturing a package at a transport terminal).

During the past 20 years, 53 transportation accidents have involved approximately 1,000 packages of commercial LLW. Of the 53 transportation accidents, only four involved the release of any LLW (for example, a package opening). Out of a total of 48 packages in those 4 shipments, 22 were damaged severely enough to release some of the contents. All of these packages were strong, tight packages and Type A packages, which are designed to withstand normal transport conditions, not accident conditions. Because of the limited quantity and concentration of the material released, however, the radiological hazard was minimal in all cases. No Type B packages were involved with a release of LLW. No injuries or deaths have been reported as resulting from the release of commercial LLW during a transportation accident. Table 5 lists all the States that have experienced transportation accidents involving LLW since 1971, along with the number of accidents in each of the States.

By comparison, 287 transportation accidents occurred in the United States in 1990 alone that involved unintentional releases of nonradioactive hazardous material, some of which resulted in injuries and deaths. ${ }^{\mathrm{gg}}$ Of the 287 accidents, 103 involved flammable-combustible liquids, 65 involved combustible liquids, and 43 involved corrosive materials. Other hazardous materials released in transportation accidents in 1990 include flammable gas, nonflammable compressed gas, oxidizers, poisonous materials, and explosives.

ff. The Radioactive Material Incident Report data base is compiled and maintained at Sandia National Laboratories-Albuquerque, New Mexico. the data base, containing transportation records for LIW from 1971 through the present, can be accessed through TRANSNET. This data is available to the public. For more information about TRANSNET, call SNL, (505) 845-8101.

gg. U.S. Department of Transportation, Annual Report on Hazardous Materials Transportation-1990, draft, DOT Research and Special Programs Administration, March 1992. 
Table 5. Transportation accidents involving commercial LLW, 1971-1991.

\begin{tabular}{lc}
\hline States & $\begin{array}{c}\text { Number of transportation } \\
\text { accidents involving commercial LLW }\end{array}$ \\
\hline Arizona & 1 \\
Colorado & 1 \\
Connecticut & 1 \\
Georgia & 1 \\
Idaho & 2 \\
Illinois & 2 \\
Iowa & 1 \\
Kentucky & 2 \\
Missouri & 2 \\
Montana & 5 \\
New Jersey & 1 \\
New York & 5 \\
North Carolina & 2 \\
North Dakota & 1 \\
Ohio & 2 \\
Pennsylvania & 2 \\
South Carolina & 10 \\
Tennessee & 1 \\
Utah & 1 \\
Virginia & 2 \\
Washington & 2 \\
West Virginia & 2 \\
Wisconsin & 1 \\
Wyoming & 2 \\
Washington, D.C. & 0 \\
All other States & \\
\hline
\end{tabular}

\subsection{Transportation Accidents Involving Commercial LLW}

There have been 53 transportation accidents involving LLW in the last twenty years. Of these 53 accidents, 49 did not involve the release of LLW. Descriptions of these 49 accidents are found in Appendix A. The following brief descriptions address the four transportation accidents to date involving the release of commercial LLW:

- The first transportation accident on record involving a release of LLW occurred on January 12, 1976. A tractor-trailer en route to the Maxey Flats, Kentucky, disposal facility was traveling on I-64, 10 miles west of Catlettsburg, Kentucky, when it struck a Kentucky Bureau of Highways truck that was spreading salt on the icy roads. A total of 12 drums containing radioactive concrete and metal went through the trailer, hit the cab, and fell off the truck. Eight of the 12 drums ruptured when they hit the highway. Responders included Kentucky State Police, Department of Human Resources, and the Civil Defense Office. 
The radiation levels were not above normal background levels expected from natural radiation, so there was no radiological hazard. The released material was repackaged in new drums and sent to the disposal site.

- On November 22, 1987, a tractor-trailer was traveling on I-80 between Cheyenne and Laramie, Wyoming, with a shipment of radioactive hoses, metal parts, and radiumcontaminated soil en route from the Quadrex Recycle Center in Oak Ridge, Tennessee, to the Richland, Washington, disposal facility. A combination of driver error and weather resulted in the truck overturning. Five of the six metal boxes fell onto the road and median, emptying approximately one-third of the contents of each container. Responders included the Wyoming State Police, Wyoming Radiological Health Services, and the Department of Highways. The material was repackaged into 12 containers and sent back to the Quadrex Recycle Center in Oak Ridge, Tennessee. Personnel from the Wyoming Radiological Health Services conducted radiological surveys and determined that no radioactivity above normal background levels was present.

- On December 31,1987, a tractor-trailer en route to the LLW disposal facility in Richland, Washington, was involved in a traffic collision and overturned on Stevens Drive in Richland. Five of the six metal boxes opened and released solid material onto the roadway. The responders included the Richland Police Department, the Department of Energy, Westinghouse, Richland Fire Department, Hanford Security, the Department of Social and Health Services (DSHS), and U.S. Ecology. The material was repackaged and sent to the disposal site. Personnel from U.S. Ecology, Westinghouse, and DSHS conducted radiological surveys and determined that no radioactivity above normal background levels was present.

- On October 24, 1989, a truck/flatbed trailer en route to the Barnwell, South Carolina, disposal facility was traveling on U.S. Hwy 460 in Christiansburg, Virginia, when the driver made a sharp left turn and the truck overturned. Four metal boxes with 384 cubic feet of soil containing uranium oxide fell off the truck and ruptured. The material covered a 25-square-foot area. Responders included local fire and police departments and Virginia State Health Department personnel. The soil was repackaged and sent to the disposal site. Radiological surveys were conducted by responders and it was determined that no radioactivity above normal background levels was present.

\subsection{Transportation Accident Conclusions}

Only four transportation accidents have involved the release of commercial LLW in the last 20 years. All the packages involved in the transportation accidents that released small quantities of material were strong, tight packages or Type A packages. Because of the limitations on radioactive material quantity and concentration imposed on these packages and because of the solid nature of LLW, the radiological hazard to the public was minimal. No Type B packages have released LLW in a transportation accident. There has never been a radiologically related death or injury due to a transportation accident involving LLW. The efficiency of local authorities responding to the accidents and their prompt remedial actions minimized any risk of exposure to the public. 


\section{SUMMARY}

States and compact regions preparing to open LLW storage and disposal facilities must address potential liabilities and risks from LLW shipments. Risks from LLW transportation are very low and can be calculated for shipments of interest to a State. Drivers and workers at LLW disposal facilities are radiation workers requiring adequate radiation safety programs. Accidents involving LLW that have occurred have been minor and the probabilities of severe accidents decreases as the magnitude of the postulated consequences increases. In the event of a transportation accident occurring in a State, the liability of that State may vary according to the individual laws of those States. 


\section{REFERENCES}

1. R. S. Garcia, Commercial Low-Level Radioactive Waste Transportation Safety History, EGG-LLW-10135 (92-2) National Low-Level Waste Management Program, March 1992.

2. U.S. Nuclear Regulatory Commission, "Technical Position on Waste Form," Revision 1, January 1991.

3. U.S. Department of Energy, 1990 State-by-State Assessment of Low-Level Radioactive Waste Received at Commercial Disposal Sites, DOE/LLW-132, National Low-Level Waste Management Program, September 1991.

4. U.S. Nuclear Regulatory Commission, Final Environmental Impact Statement on the Transportation of Radioactive Material by Air and Other Modes, NUREG-0170, 1977.

5. K. S. Neuhauser, F. L. Kanipe, RADTRAN 4.0: Volume 3 User Guide, SAND89-2370, Sandia National Laboratories, January 1992.

6. J. W. Cashwell, "TRANSNET-Access to Transportation Models and Databases," Proceedings of the 9th International Symposium on Packaging and Transportation of Radioactive Materials (PATRAM '89), Alexandria, Virginia, June 1989, pp. 619-625.

7. J. M. Taylor, S. L. Daniel, RADTRAN: A Computer Code to Analyze Transportation of Radioactive Material, SAND76-0243, Sandia National Laboratories, April 1977.

8. J. M. Taylor, S. L. Daniel, RADTRAN II: A Revised Computer Code to Analyze Transportation of Radioactive Material, SAND80-1943, Sandia National Laboratories, October 1982.

9. M. M. Madsen, J. M. Taylor, R. M. Ostmeyer, P. C. Reardon, RADTRAN III, SAND84-0036, Sandia National Laboratories, February 1986.

10. U. S. Nuclear Regulatory Commission, "Calculation of Reactor Consequences," Appendix VI, Reactor Safety Study, WASH-1400, October 1975.

11. National Research Council Committee on the Biological Effects of Ionizing Radiation, Health Effects of Exposure to Low Levels of Ionizing Radiation: BEIR V, National Academy Press, Washington, D.C., 1990.

12. J. S. Evans, Health Effects Models for Nuclear Power Plant Accident Consequences Analysis, NUREG CR-4124, Nuclear Regulatory Commission, July 1985.

13. M. M. Madsen, E. L. Wilmot, J. M. Taylor, RADTRAN II User Guide, SAND82-2681, Sandia National Laboratories, February 1983. 
14. R. M. Ostmeyer, N. C. Finley, J. W. Cashwell, J. D. McClure, The Potential Consequences and Risks of Highway Accidents Involving Gamma-Emitting Low Specific Activity (LSA) Waste, SAND87-2808, Sandia National Laboratories, August 1988.

15. J. M. Shuler, "A Comparison of Yearly Radiation Dose to Drivers from Various Types of Radioactive Materials," Proceedings of the 9th International Symposium on Packaging and Transportation of Radioactive Materials (PATRAM '89), Alexandria, Virginia, June 1989, pp. 430437.

16. R. F. Weiner, P. A. LaPlante, J. P. Hageman, F. Bennett, J. Buckingham, "Risks in Transporting Radioactive Materials: Comparison of Data with NUREG-0170 Projections," Proceedings of Waste Management 90, University of Arizona, Tucson, Arizona, 1990.

17. J. D. McClure, Methodology for Estimating the Risk of Transporting Low-Level Radioactive Waste in the US, SAND-82-0482C, Sandia National Laboratories, April 1982.

18. N. C. Finley, R. E. Luna, M. M. Madsen, J. D. McClure, T. A. Wheeler, E. L. Wilmot, The Transportation of Radioactive Material (RAM) To and From U.S. Nuclear Power Plants: Draft Environmental Assessment, NUREG/CR-2325, SAND81-0118, Sandia National Laboratories, Albuquerque, New Mexico, December 1983.

19. R. E. Luna, M. M. Madsen, E. L. Wilmot, J. M. Taylor, "Generic Evaluation of the Radiological Impacts of Transportation in the Nuclear Fuel Cycle," Proceedings of the International Symposium on Packaging and Transportation of Radioactive Materials, pp. 357-364.

20. L. L. Humphries, B. Dodd, "Risks of Radioactive Material Transportation Accidents in Oregon," Health Physics, 57, 1 July 1989, pp. 131-139.

21. C. A. Geffen, "Risk Methodologies for the Transportation of Radioactive Materials," Proceedings of the International Symposium on Packaging and Transportation of Radioactive Materials (PATRAM '83), 1983, p. 317.

22. U.S. Department of Energy, Guidelines for Selecting Preferred Highway Routes for Highway Route Controlled Quantity Shipments of Radioactive Materials, DOT/RSPA/OHMT-89/01, January 1989.

23. Battelle Memorial Institute, Alternative Site Investigation Studies, Martinsville Alternative Site, Clark County, Illinois, 1990.

24. Murray, R.L., Understanding Radioactive Waste, 1989.

25. C. E. Cashwell, Transportation Accidents/Incidents Involving Radioactive Materials, SAND-90-7025C, Sandia National Laboratories, December 1990. 
26. H. S. Javitz, T. R. Lyman, C. Maxwell, E. L. Myers, and C. R. Thompson, Transportation of Radioactive Material in the United States: Results of a Survey to Determine the Magnitude and Characteristics of Domestic Unclassified Shipments of Radioactive Materials, SAND84-7174, Sandia National Laboratories, 1985. 


\section{BIBLIOGRAPHY}

Ahearne, J. F., "Public Risk Communication," Proceedings of the 9th International Symposium on Packaging and Transportation of Radioactive Materials, 1989, pp. 8-17.

Andrews, W. B., R. E. Rhoads, A. L. Franklin, "Transportation Risks Moving Waste Products from Nuclear Power Generation," Professional Safety 9, November 1981.

Ardila-Coulson, M. V., "Use of StateGEN for the Routing Analysis of Transporting Radioactive Materials," Proceedings of the 9th International Symposium on Packaging and Transportation of Radioactive Materials (PATRAM '89), Alexandria, Virginia, June 1989, pp. 590-595.

Bailey, W. J., D. C. Langstaff, "Experience with Fuel Damage from Abnormal Conditions in Handling and Transport," Proceedings of the International Symposium on Packaging and Transportation of Radioactive Materials (PATRAM '80), 1980, pp. 195, 1113.

Balmert, M. E., et al., "Fuel Response to Severe Transportation Accidents," Proceedings of the International Symposium on Packaging and Transportation of Radioactive Materials (PATRAM '80), 1980, pp. 162, 762.

Brogan, J. D., J. W. Cashwell, "Identifying Roadway Sections With "Critical" Large Truck Accident Rates," Proceedings of the 9th International Symposium on Packaging and Transportation of Radioactive Materials, pp. 1081-1088, 1989.

Brown, O. F., "Recent Developments in the Area of Insurance and Indemnity Coverage for Transportation of Radioactive Materials in the United States," Proceedings of 9th International Symposium on Packaging and Transportation of Radioactive Materials (PATRAM '89), Alexandria, Virginia, June 1989, Vol. II p. 843.

Brown, O. F., Insurance-Indemnity Coverage for Nuclear Transportation: An Overview, SAND85-7260, TTC-0607, Sandia National Laboratories, January 1986.

Burian, R. J., K. K. Kok, R. P. Sandoval, "Experimental Determination of Radionuclide Release and Transport from Spent Fuel Exposed to Cask Fire Environments," Proceedings of the International Symposium on Packaging and Transportation of Radioactive Materials (PATRAM '83), 1983, p. 304.

Cashwell, J. W., K. S. Neuhauser, P. C. Reardon, G. W. McNair, Transportation Impacts of the Commercial Radioactive Waste Management Program, SAND85-2715, Sandia National Laboratories, April 1986.

Cashwell, J. W., "TRANSNET_Access to Transportation Models and Databases," Proceedings of the 9th International Symposium on Packaging and Transportation of Radioactive Materials (PATRAM '89), Alexandria, Virginia, June 1989, pp. 619-625. 
Cashwell, J. W., R. E. Luna, and K. S. Neuhauser, The Impacts of Transportation Within the United States of Spent Reactor Fuel from Domestic and Foreign Research Reactors, SAND 88-0714, Sandia National Laboratories, 1990.

Cashwell, J. W., K S. Neuhauser, "Analyses of the Transportation of Spent Research Reactor Fuel in the United States," Proceedings of the 9th International Symposium on Packaging and Transportation of Radioactive Materials, 1989, pp. 1066-1073.

Cohrssen, J. J., V. T. Covello, Risk Analysis: A Guide to Principles and Methods for Analyzing Health and Environmental Risks, Council on Environmental Quality, Washington, D.C., 1990.

Colton, J. D., et al., Transport of Low Specific Activity Materials, NUREG/CR-2440, SRI International, Menlo Park, California, 1981.

Columbia University, Financial Protection Against Nuclear Hazards: Thirty Years' Experience Under the Price-Anderson Act, Trustees of Columbia University, New York, New York, 1984.

Congressional Research Service, Nuclear Materials Transportation: Safety Concerns, Governmental Regulations and Activities, and Options to Improve Federal Programs, Report No. 84-45SPR, Library of Congress, March 1984.

Curren, W. D., Bond, R. D., "Leakage of Radioactive Powders from Containers," Proceedings of the International Symposium on Packaging and Transportation of Radioactive Materials (PATRAM '80), 1980, pp. 65, 463.

Dennis, A. W., J. T. Foley, W. F. Hartman, D. W. Larsen, Severities of Transportation Accidents Involving Large Packages, SAND77-0001, Sandia National Laboratories, May 1978.

Eisenberg, N. A., "Transport of Radionuclides in Urban Environs," Proceedings of the International Symposium on Packaging and Transportation of Radioactive Materials (PATRAM '80), 1980, pp. 113,728 .

Elder, H. K., et. al., An Assessment of the Risk of Transporting Spent Nuclear Fuel by Truck, PNL2588, Pacific Northwest Laboratory, November 1978.

Emerson, E. L., J. D. McClure, Accident-Incident History in the Transportation of LLW Since 1971, SAND82-1417, Sandia National Laboratories, August 1982.

Emerson, E. L., J. D. McClure, The Nature of Transportation Accidents Involving Radioactive Material Packagings, SAND80-1330C, Sandia National Laboratories, October 1981.

Finley, N. C., J. D. McClure, P. C. Reardon, M. Wangler, "An Analysis of the Consequences of Accidents Involving Shipments of Multiple Type A Radioactive Material (RAM) Packages," Proceedings of the 9th International Symposium on Packaging and Transportation of Radioactive Materials, 1989, pp. 1043-1049. 
Finley, N. C., et al., "Environmental Impacts of the Transportation of Radioactive Materials in Urban Areas," Proceedings of the International Symposium on Packaging and Transportation of Radioactive Materials (PATRAM '80), 1980, pp. 183, 723.

Finley, N. C., et. al., Transportation of Radionuclides in Urban Environs: Draft Environmental Assessment, SAND79-0369, Sandia National Laboratories, July 1980.

Finley, N. C., R. E. Luna, M. M. Madsen, J. D. McClure, T. A. Wheeler, E. L. Wilmot, The Transportation of Radioactive Material (RAM) To and From U.S. Nuclear Power Plants: Draft Environmental Assessment, NUREG/CR-2325, SAND81-0118, Sandia National Laboratories, December 1983.

Franklin, A. L., R. E. Rhoads, W. B. Andrews, "Risks in U.S. Energy Material Transportation," IAEA-SM-254/59, Health Impacts of Different Sources of Energy, 499, Vienna, Austria, 1982.

Funk, C. W., L. D. Jacobson, Spent Fuel Integrity During Transportation, HEDL-TME-78-58, January 1980.

Geffen, C. A., "Risk Methodologies for the Transportation of Radioactive Materials," Proceedings of the International Symposium on Packaging and Transportation of Radioactive Materials (PATRAM '83), 1983, p. 317.

Grella, A. W., "Accident Experiences in the USA Involving Type B Packaging," IAEA-SM-147/19, Seminar on Test Requirements for Packaging for the Transport of Radioactive Materials, Vienna, Austria, February 1971.

Hubner, H. W., B. Schulz-Forberg, "Classification and Safety Margins of RAM Packagings," Proceedings of the International Symposium on Packaging and Transportation of Radioactive Materials (PATRAM '83), 1983, pp. 90, 1254.

Hull, A. P., E. T. Lessard, Risk Comparisons for the Transportation of Spent Fuel from Nuclear Reactors, BNL-36390, Brookhaven National Laboratory, April 1985.

Humphries, L. L., B. Dodd, "Risks of Radioactive Material Transportation Accidents in Oregon," Health Physics, 57, 1 July 1989, pp. 131-139.

Jefferson, R. M., J. D. McClure, "Regulation Versus Reality," Proceedings of the International Symposium on Packaging and Transportation of Radioactive Materials (PATRAM '83), 1983, p. 1,633 .

Joy, D. S., P. E. Johnson, S. M. Gibson, HIGHWAY, A Transportation Routing Model: Program Description and User's Manual, ORNL/TM-8419, Oak Ridge National Laboratory, December 1982.

Joy, D. S., P. E. Johnson, D. B. Clarke, S. C. McGuire, "Predicting Transportation Routes for Radioactive Wastes," Waste Management 1981, University of Arizona, Tucson, Arizona, p. 415. 
Levinson, M., F. Rahn, "Realistic Estimates of the Consequences of Nuclear Accidents," Nuclear Technology 53, May 1981, p. 10.

Luna, R. E., NCRP Fuel Cycle Risk Report, SAND83-2128, Sandia National Laboratories, February 1984.

Luna, R. E., M. M. Madsen, E. L. Wilmot, J. M. Taylor, "Generic Evaluation of the Radiological Impacts of Transportation in the Nuclear Fuel Cycle," Proceedings of the International Symposium on Packaging and Transportation of Radioactive Materials, 1983, pp. 357-364.

Madsen, M. M., E. L. Wilmot, J. M. Taylor, RADTRAN II User Guide, SAND82-2681, Sandia National Laboratories, February 1983.

Madsen, M. M., E. L. Wilmot, "Truck Transportation of Radioactive Materials," Proceedings of the International Symposium on Packaging and Transportation of Radioactive Materials (PATRAM '83), 1983, pp. 724-731.

Madsen, M. M., J. M. Taylor, R. M. Ostmeyer, P. C. Reardon, RADTRAN III, SAND84-0036, Sandia National Laboratories, February 1986.

Mairs, J. H., K. B. Shaw, "Methodologies for Assessing the Radiological Impact Arising from the Transport of Radioactive Materials," Proceedings of the 8th International Symposium on Packaging and Transportation of Radioactive Materials, 1986, pp. 361-370.

McClure, J. D., The Probability of Spent Fuel Transportation Accidents, SAND80-1721, Sandia National Laboratories, July 1981.

McClure, J. D., Methodology for Estimating the Risk of Transporting Low-Level Radioactive Waste in the U.S., SAND-82-0482C, Sandia National Laboratories, April 1982.

McClure, J. D., R. E. Luna, Public Concerns About RAM Transport-Communicating Engineering Data on Risk, SAND-2656C, Sandia National Laboratories, 1988.

McClure, J. D., A. Tyron-Hopko, Radioactive Material (RAM) Transportation Accident/Incident Analysis, SAND85-1016, Sandia National Laboratories, March 1986.

McClure, J. D., E. L. Emerson, "A Review of U.S. Accident/Incident Experience Involving the Transportation of Radioactive Material (RAM) 1971-1980,"Proceedings of the International Symposium on Packaging and Transportation of Radioactive Materials (PATRAM '80), 1980, pp. $187,811$. 
Mishima, J., "Potential Aerosol Generation Mechanisms from Damaged Shipping Packages," IAEA-SR-10/15, Transport Packaging for Radioactive Materials, Vienna, Austria, 1976.

National Research Council, Improving Risk Communication, Committee on Risk Perception and Communication, National Academy Press, Washington, D.C., 1989.

National Research Council Committee on the Biological Effects of Ionizing Radiation, Health Effects of Exposure to Low Levels of Ionizing Radiation: BEIR V, National Academy Press, Washington, D.C., 1990.

Neuhauser, K. S., F. L. Kanipe, RADTRAN 4.0: Volume 3 User Guide, SAND89-2370, Sandia National Laboratories, January 1992.

Neuhauser, K. S., J. W. Cashwell, P. C. Reardon, G. W. McNair, A Preliminary Cost and Risk Analysis for Transporting Spent Fuel and High Level Wastes to Candidate Repository Sites, SAND84-1795, Sandia National Laboratories, April 1984.

Neuhauser, K. S., P. C. Reardon, A Demonstration Sensitivity Analysis for RADTRAN III, SAND851001, Sandia National Laboratories, October 1986.

Neuhauser, K. S., P. C. Reardon, "RADTRAN 4.0 - Advanced Computer Code for Transportation Risk Assessment," SAND89-1137c, Proceedings of the 9th International Symposium on Packaging and Transportation of Radioactive Materials (PATRAM '89), Alexandria, Virginia, June 1989, pp. $1,074-1,080$.

Oak Ridge National Laboratory, INTERLINE, A Railroad Routing Model: Program Description and User's Manual, ORNL/TM-8944, November 1985.

Oak Ridge National Laboratory, HIGHWAY, A Transportation Routing Model: Program Description and Revised User's Manual, ORNL/TM-8759, October 1983.

Ostmeyer, R. M., N. C. Finley, J. W. Cashwell, J. D. McClure, The Potential Consequences and Risks of Highway Accidents Involving Gamma-Emitting Low Specific Activity (LSA) Waste, SAND87-2808, Sandia National Laboratories, August 1988.

Pacific Northwest Laboratory, Analysis of Radiation Doses from Operation of Postulated Commercial Spent Fuel Transportation Systems, DOE/CH/TPO-001, 1987.

Pacific Northwest Laboratory, Risks in U.S. Energy Material Transportation, PNL-SA-8545, 1981.

Peterson, R. W., et al., "Estimated Transportation Cost and Risk for Operation of a Nuclear Waste Repository," Proceedings of the International Symposium on Packaging and Transportation of Radioactive Materials (PATRAM '83), 1983, p. 278.

Rao, R. K., E. L. Wilmot, R. E. Wilmot, Non-Radiological Impacts of Transporting Radioactive Material, SAND81-1703, Sandia National Laboratories, February 1983. 
Reese, R. T., et al., "Relative Consequences of Transporting Hazardous Materials," Proceedings of the International Symposium on Packaging and Transportation of Radioactive Materials (PATRAM '80), 1980, pp. 158, 197.

Rhoads, R. E., J. F. Johnson, "Risks in Transporting Materials for Various Energy Industries," Nuclear Safety, 19, 2, March-April 1978.

Schwendiman, L. C., et al., "Research Progress on Particle Transmission Through Very Small Openings," Proceedings of the International Symposium on Packaging and Transportation of Radioactive Materials (PATRAM '80), 1980, pp. 101, 279.

Shuler, J. M., "A Comparison of Yearly Radiation Dose to Drivers from Various Types of Radioactive Materials," Proceedings of the 9th International Symposium on Packaging and Transportation of Radioactive Materials (PATRAM '89), Alexandria, Virginia, June 1989, pp. 430437.

Smith, R. N., E. L. Wilmot, Truck Accident and Fatality Rates Calculated From California Highway Accident Statistics for 1980 and 1982, SAND82-7006, Sandia National Laboratories, November 1982.

Southern States Energy Board, Lessons Learned by Southern States in Designating Alternative Routes, Southern States Energy Board, Norcross, Georgia, January 1992.

Southern States Energy Board, Spent Fuel and High-Level Radioactive Waste Transportation Report, Southern States Energy Board, Norcross, Georgia, January 1992.

Taylor, J. M., S. L. Daniel, RADTRAN II: A Revised Computer Code to Analyze Transportation of Radioactive Material, SAND80-1943, Sandia National Laboratories, October 1982.

U.S. Atomic Energy Agency, Environmental Survey of Transportation of Radioactive Materials to and From Nuclear Power Plants, WASH-1238, December 1972.

U.S. Department of Energy, Final Environmental Impact Statement Waste Isolation Pilot Plant, DOE/EIS-0026, 1980.

U.S. Department of Energy, Guidelines for Selecting Preferred Routes for Large Quantity Shipments of Radioactive Materials, DOT-RSPA/MTB-81, June 1981.

U.S. Department of Energy, Guidelines for Selecting Preferred Highway Routes for Highway Route Controlled Quantity Shipments of Radioactive Materials, DOT/RSPA/OHMT-89/01, January 1989.

U.S. Department of Energy, Nuclear Waste Policy Act Environmental Assessment, Yucca Mountain Site, DOE/RW-0073, Office of Civilian Radioactive Waste Management, May 1986.

U.S. Nuclear Regulatory Commission, Final Environmental Impact Statement on the Transportation of Radioactive Material by Air and Other Modes, NUREG-0170, 1977. 
U.S. Nuclear Regulatory Commission, Shipping Container Response to Severe Highway and Railway Accident Conditions, NUREG/CR-4829, UCID-20733, February 1987.

U.S. Nuclear Regulatory Commission, "Calculation of Reactor Consequences," Appendix VI, Reactor Safety Study, WASH-1400, October 1975.

U.S. Nuclear Regulatory Commission, Radioactive Material (RAM)Accident/Incident Analysis Program, NUREG/CR-3611, Sandia National Laboratories, March 1985.

U.S. Nuclear Regulatory Commission, Transporting Spent Fuel, NUREG/BR-0111, March 1987.

Wehner, G., "Safety Philosophy and Acceptable Risk," Proceedings of the International Symposium on Packaging and Transportation of Radioactive Materials (PATRAM '80), 1980, pp. 99, 15.

Weiner, R. F., P. A. LaPlante, J. P. Hageman, "An Approach to Assessing the Impacts of IncidentFree Transportation of Radioactive Materials: I. Air Transportation," Risk Analysis, 11, 4, 1991.

Weiner, R. F., P. A. LaPlante, J. P. Hageman, "An Approach to Assessing the Impacts of IncidentFree Transportation of Radioactive Materials: II. Highway Transportation," Risk Analysis, II, 4, 1991.

Weiner, R. F., P. A. LaPlante, J. P. Hageman, F. Bennett, J. Buckingham, "Risks in Transporting Radioactive Materials: Comparison of Data with NUREG-0170 Projections," Proceedings of Waste Management '90, University of Arizona, Tucson, Arizona, 1990.

Wilmot, E. L., R. E. Luna, Worst-Case Scenario Syndrome, SAND80-0021A, Sandia National Laboratories, March 1980.

Wilmot, E. L., M. M. Madsen, J. W. Cashwell, D. S. Joy, A Preliminary Analysis of the Cost and Risk of Transporting Nuclear Waste to Potential Candidate Commercial Repository Sites, SAND830867, Sandia National Laboratories, June 1983.

Wilmot, E. L., et al., Report on a Workshop on Transportation Accident Scenarios Involving Spent Fuel - May 6-8, 1980, SAND80-2012, Sandia National Laboratories, February 1981.

Wilmot, E. L., Transportation Accident Scenarios for Commercial Spent Fuel SAND80-2124, Sandia National Laboratories, February 1981. 



\section{Appendix A}

\section{Transportation Accidents Involving LLW}

Without Releases of LLW 
. 


\section{Appendix A}

\section{Transportation Accidents Involving LLW Without Releases of LLW}

No release of material or radioactivity was associated with these 49 LLW transportation accidents. Brief descriptions address these accidents as follows:

03/09/73 A tractor-trailer transporting a cask containing spent resins en route from Vermont Yankee Nuclear Power Plant to Barnwell, South Carolina, was traveling on U.S. 301, 3 miles south of Orangeburg, South Carolina, when the brakes failed at the intersection of Hwy 70 and US 301. To avoid oncoming traffic, the driver maneuvered the truck across the median and hit a passenger car. The cask fell off the trailer and bent the drain plug and eyes on the side of the cask. No radioactivity was released.

06/14/74 A train transporting LLW en route from Ohio to Richland, Washington, was traveling 3 miles east of Deer Lodge, Montana, when it derailed. The cargo included 211 steel drums containing solidified waste containing 28.55 grams of plutonium-238 (491 Ci). The drums were not damaged and it was determined that no release of radioactivity occurred.

08/07/74 A tractor-trailer transporting LLW en route from New Hampshire to the former Maxey Flats facility in Kentucky was traveling on I-77 in Ohio. The driver was going down an incline with a sharp curve at the bottom. As he rounded the curve, his trailer tandems went off the right side of the pavement. The trailer tilted and a cask containing LLW rolled off the trailer and landed in a ditch. The cask was the only cargo and it was not damaged. No radioactivity was released.

08/14/74 A truck transporting LLW en route from the Oyster Creek Nuclear Power Plant in New Jersey to the former Maxey Flats facility in Kentucky entered Nuclear Energy Company grounds in Kentucky on a narrow one-lane road. The trailer tandems went off the road onto the muddy shoulder. The truck overturned, but the cask containing LLW stayed on the trailer and remained intact. The only cargo was this cask, and it was undamaged. No radioactivity was released.

01/06/75 A tractor-trailer transporting LLW en route from Wilmington, North Carolina, to Barnwell, South Carolina, was traveling near the intersection of I-95 and SC 378 in South Carolina when it was broadsided by a 2 -ton truck. The shipment included 15 wooden boxes containing uranium-235 waste. The boxes were not damaged and no radioactivity was released.

01/22/75 A van pulling a trailer transporting LLW en route from Maryland to Barnwell, South Carolina, was traveling in Washington, D.C., when it jackknifed near the intersection of I-495 and Hwy 1, hit another vehicle, and then hit the guardrail. The shipment included eight 5-gallon pails, 8255 -gallon drums, and seven 8-cubic-foot boxes. Out of this shipment of 97 strong, tight packages, eight were damaged, but no radioactivity was released. 
10/23/75 A truck with a flatbed trailer transporting LLW en route from the Oyster Creek Nuclear Power Plant in New Jersey to the former Maxey Flats facility in Kentucky was traveling near Morgantown, West Virginia, when it ran off the road and overturned. The shipment included a Type A cask containing LLW. The cask was thrown off the trailer, but it was not damaged. No radioactivity was released.

03/15/76 A tractor-trailer transporting spent resins en route from Vermont Yankee Nuclear Power Plant to the former Maxey Flats facility in Kentucky was traveling on the Beacon Bridge on I-84 in New York when the truck was involved in a minor accident. The total activity being transported was $300 \mathrm{mCi}$ of spent resins in a Type A package. The shipment was undamaged and no radioactivity was released.

04/05/76 A drop-frame trailer transporting a 30-thousand-pound cask containing LLW en route from the Northeast Utilities Millstone Power Plant in Connecticut to Kentucky was traveling on Hwy 66, south of Middleton, Connecticut, when it struck an overpass. The cask was not damaged and no radioactivity was released.

08/06/76 A truck with an open top trailer transporting demineralizers en route from the Charleston Naval Shipyard in South Carolina to Barnwell, South Carolina, was traveling near SC 39 and US 278 near Snelling, South Carolina, when the driver applied the brakes on an approach to a stop sign and felt the load shift. He applied the brakes again before reaching the intersection and tried to make a left turn. As a result, the truck turned on its side; two demineralizer casks went through the cloth top of the trailer, and one went through the trailer. The three casks containing the demineralizers were undamaged and no radioactivity was released.

09/08/77 A tractor-trailer transporting LLW en route from the Oyster Creek Nuclear Power Plant in New Jersey to Barnwell, South Carolina, was traveling on a road in South Carolina when the driver swerved to miss a turning car and ran up an embankment into a field. The shipment included a cask containing solidified evaporator bottoms. The cask was undamaged and no radioactivity was released.

11/09/77 A tractor-trailer carrying LLW en route from Vermont Yankee Nuclear Power Plant to Barnwell, South Carolina, was traveling on I-95, 15 miles north of Rocky Mount, North Carolina, when the driver rear-ended another truck. The shipment included one cask containing LLW, which remained intact. No radioactivity was released.

04/05/78 A truck transporting LLW en route from the Robert E. Ginna Nuclear Plant in New York to Barnwell, South Carolina, was traveling near Winchester, Virginia, when it had a tire blowout. The LLW was transported in strong, tight packages. The shipment shifted, but it was resecured. The shipment was not damaged and no radioactivity was released.

07/07/78 A tractor-trailer transporting LLW en route from the Millstone Nuclear Power Plant in Connecticut to Barnwell, South Carolina, was traveling downgrade on US 301, south of Orangeburg, South Carolina. As it approached an intersection, a car in front of the truck stopped to avoid a collision, and the truck swerved and hit a utility pole. The shipment was 
a Type B cask containing mixed fission products. The trailer and cask were undamaged and no radioactivity was released.

08/29/78 A truck transporting LLW en route from Illinois to Barnwell, South Carolina, was traveling on I-24 near the Tennessee-Georgia border when it struck a guardrail and overturned. The shipment consisted of 18 55-gallon steel drums of solidified reactor coolant packed inside a cask. The cask was not damaged and no radioactivity was released.

09/13/78 A tractor-trailer transporting a contaminated lifting yolk en route from Nebraska to Barnwell, South Carolina, was traveling on I-70, west of St. Louis, Missouri, when the yolk broke through the trailer floor. The yolk was raised, shored, and fastened without incident and the truck continued on its route to Barnwell, South Carolina. No radioactivity was released.

12/19/78 A truck transporting LLW en route from Minnesota to the former Sheffield facility in Illinois was traveling on I-90/94, 20 miles north of Madison, Wisconsin, when the driver swerved to avoid colliding with a car that was out of control. The rig overturned in the median. The shipment included 3955 -gallon drums containing depleted uranium-238 waste. The drums were undamaged and the seals were intact. No radioactivity was released.

01/28/79 A tractor-trailer transporting LLW en route from Dresden, Illinois to Barnwell, South Carolina, was traveling on I-24 east, near Monteagle, Tennessee. The truck was traveling in excess of $45 \mathrm{mph}$ on a steep, icy grade when another vehicle pulled in front of it. The driver lost control and the truck overturned. Forty-six 55-gallon drums containing contaminated clothes and rags fell out onto the highway. Four drums were damaged, but there was no release of radioactivity.

03/20/79 A tractor-trailer transporting LLW en route from Nebraska to Barnwell, South Carolina, was stopped on the shoulder of I-70, 60 miles west of St. Louis, Missouri, when it was struck from behind by a meat truck. The shipment consisted of 57 55-gallon steel drums and one wooden box. All packages contained mixed fission products. Most of the material consisted of evaporator concentrates solidified in concrete. Two steel drums and the box were damaged, but no radioactivity was released.

06/18/79 A tractor-trailer transporting LLW en route from Commonwealth Edison Company in Illinois to Barnwell, South Carolina, was traveling on I-26, 25 miles northwest of Columbia, South Carolina, was it was involved in an accident. The shipment included 14 drums of spent resins in a Type A cask. The cask remained undamaged and no radioactivity was released.

08/03/79 A pickup truck was transporting LLW en route from a laundry near Barnwell, South Carolina, to the disposal facility in Barnwell when it was involved in an accident. The truck was transporting a container of slightly contaminated clothing. The clothing had been laundered at a laundry and was being returned to Chem-Nuclear Systems, Inc., the operator of the facility. No radioactivity was released. 
12/09/79 A tractor-trailer transporting LLW en route to Richland, Washington, was traveling in foggy weather on an icy I-90, 12 miles west of Missoula, Montana, when it hit an abandoned car parked on the shoulder of the road. The shipment consisted of a wooden box containing $1 \mathrm{Ci}$ of noncompacted LLW. The box was not damaged and no radioactivity was released.

12/12/79 A tractor-trailer transporting LLW en route from the University of Wisconsin to Richland, Washington, was traveling on I-90, 1 mile east of St. Regis, Montana, when it was struck on the left front corner of the cab by a car driven by a drunk driver. The shipment contained carbon-14 from the Engineering Department of the University of Wisconsin. The packages were undisturbed and no radioactivity was released.

01/11/80 A truck transporting LLW on Rt 9 in Montrose, New York, was involved in an accident. The shipment included two 5-gallon pails and seven 55-gallon steel drums containing LLW. The pails and drums were intact and no radioactivity was released.

01/31/80 A tractor-trailer transporting uranium and mixed fission products en route from New York to Barnwell, South Carolina, was traveling on I-95 near Roanoke Rapids, North Carolina, when it jackknifed and came to rest on the median. The shipment included one cask containing 230 grams of uranium and $700 \mathrm{Ci}$ of mixed fission products, and another cask containing 238 grams of uranium and $933 \mathrm{Ci}$ of mixed fission products. The casks were both Type B packages. Two other vehicles were involved, but there were no injuries. The casks were undamaged and no radioactivity was released.

02/15/80 A tractor-trailer transporting krypton-85 en route from Arizona to Barnwell, South Carolina, was traveling in Phoenix, Arizona, when it tried to avoid a car that pulled out in front of it. A 20-pound fiberboard box containing a source tube with $450 \mathrm{mCi}$ of krypton- 85 shifted position. The radiation level outside the box increased to $30 \mathrm{mR} / \mathrm{hr}$ at the surface. Although there was no release of materials, the box was returned to the shipper for repackaging.

02/22/80 A tractor-trailer transporting LLW en route from Ohio to Beatty, Nevada was traveling on I-70, west of Columbus, Ohio, when it was struck in the side by a pickup truck as it was leaving a truck stop. The LLW was packed in strong, tight packages. No radioactivity was released.

04/18/80 A tractor-trailer transporting LLW en route from Metropolitan Edison Company in Pennsylvania to Barnwell, South Carolina, was traveling on Grant Street in Middleton, Pennsylvania, when the rig decoupled at an intersection. The trailer dropped down on a parking dolly. The rig was recoupled and driven to a truck stop for inspection. The shipment included a cask containing LLW. The cargo was not damaged and no radioactivity was released.

06/22/80 A tractor-trailer transporting LLW en route from the Monticello Nuclear Power Plant in Minnesota to Richland, Washington, was traveling near Glendive, Montana, when a sudden, strong gust of wind caused the truck to jackknife and slide into a ditch. The shipment included eight wooden boxes and 1655 -gallon steel drums. The response team 
surveyed the undamaged boxes and drums and determined that no radioactivity was released.

12/22/80 A tractor-trailer transporting LLW en route from the Northeast Nuclear Energy Company in Connecticut to Barnwell, South Carolina, was traveling near Bordentown, New Jersey, when it was involved in an accident. The shipment included a Type A cask containing 570 $\mathrm{mCi}$ of mixed fission products. The trailer and the cask were undamaged and no radioactivity was released.

06/16/81 A tractor-trailer transporting dewatered resins en route from the Salem Nuclear Power Plant in New Jersey to Barnwell, South Carolina, was traveling on I-95, south of Dillon, South Carolina, when it rear-ended another tractor-trailer. The tractor was damaged, but the cargo remained intact. The cargo included a Type A cask containing 200 cubic feet of dewatered resins and $3 \mathrm{Ci}$ of activated corrosion products. No radioactivity was released.

08/12/81 A tractor-trailer transporting LLW en route from Florida to Barnwell, South Carolina, was passing a farm tractor on Rt 3, north of US 601 in South Carolina, when a collision occurred. The shipment included LLW consisting of $0.592 \mathrm{Ci}$ of general trash (cloth, plastic, wood, gloves, etc.) from the Turkey Point Nuclear Power Plant in Florida. The cask was not damaged and no radioactivity was released.

11/23/81 A tractor with two trailers transporting LLW en route from Colorado, to Beatty, Nevada was traveling on U.S. 6, west of I-70 near Denver, Colorado, when it slid off the highway into a snowbank. The shipment included 28 fiberboard boxes (14 in each trailer) containing nitrate salts with americium and uranium oxidizers and $0.00171 \mathrm{Ci}$ of plutonium. The boxes were not damaged and no radioactivity was released.

01/07/82 A tractor-trailer transporting LLW en route from Cincinnati, Ohio to Richland, Washington, was traveling on I-86, east of Burley, Idaho, when the truck slid off the icy road into the snow. The cargo was not damaged and no radioactivity was released.

05/06/82 A tractor-trailer transporting LLW en route from Ohio to California was traveling near the intersection of I-15 and 54 Street in Salt Lake City, Utah, when an oil line ruptured, spraying oil onto the engine, and caused a fire to the tractor portion of the vehicle. The shipment included LLW consisting of depleted uranium. The package was undamaged and no radioactivity was released.

11/03/82 A tractor-trailer transporting two empty Type B casks en route from Barnwell, South Carolina, to New York was traveling near Hilda, South Carolina, when a car pulled out in front of the truck, causing the truck to overturn. Both cask tie-downs gave way and the casks were thrown from the trailer. The tractor caught fire. Both casks were intact and undamaged. No radioactivity was released.

12/14/82 A tractor-trailer transporting LLW en route from the University of Minnesota to Richland, Washington, was traveling on I-94 on the Exit 1 off ramp near Beach, North Dakota, when it ran off the road into a ditch because the driver was unable to negotiate the exit ramp due to icy road conditions. The truck ended up in an upright position. The shipment 
included 55-gallon steel drums containing tritium, iodine-125, iron-55, and carbon-14 totaling $1373.07 \mathrm{mCi}$ and 1275 cubic feet of material. The drums remained intact and no radioactivity was released.

03/11/83 A tractor-trailer transporting a Type B cask containing LLW en route from Wisconsin to Richland, Washington, was traveling on Ill 59 at Ill 64 in Illinois when it was side-swiped by another truck. The cask was not damaged and no radioactivity was released.

06/22/83 A tractor-trailer transporting LLW en route from New York, New York, to Richland, Washington, was traveling on I-95 South trying to take the exit to the George Washington Bridge when a car struck the back of the trailer. The shipment included 177 55-gallon drums of LLW containing iodine-125, carbon-14, and phosphorus-32 from New England hospitals. Five nonradiologically related injuries resulted from the collision, but the shipment was undamaged. No radioactivity was released.

10/11/83 A truck with a flatbed trailer transporting LLW en route from Pennsylvania to Richland, Washington, was traveling on U.S. 250 near Cameron, West Virginia, when the driver went left of center and struck an oncoming auto on the winding road. The shipment consisted of five Type A steel canisters containing LLW from Consolidation Coal in Jollytown, Pennsylvania. The canisters were undamaged and no radioactivity was released.

12/18/83 A tractor-trailer transporting LLW en route from Philadelphia, Pennsylvania, to Richland, Washington, was traveling on an icy I-84 near King Hill, Idaho, when the driver tried to avoid hitting a car and slid into a rock wall. The shipment consisted of containers of compacted LLW. One container needed an overpack to continue to Richland. The other containers were undamaged. There was no contamination and no radioactivity was released.

05/04/84 A tractor-trailer transporting LLW en route from Ohio to Beatty, Nevada was traveling on I-70 near Greenville, Illinois, when a fire erupted from the right rear drive axle. The right front side of the trailer was burned and two boxes were scorched. The shipment included 19 wooden boxes containing LLW. Although two boxes were damaged, no radioactivity was released.

05/28/84 A tractor-trailer transporting LLW en route from New Jersey to Richland, Washington, was traveling on I-80, 30 miles east of Rock Springs, Wyoming, when the truck overturned. The shipment included 15 fiberboard boxes containing carbon-14, technetium-99, and iodine-129. The boxes were unloaded and transferred to another trailer and taken to Rock Springs for transfer to another vehicle. The boxes were undamaged and no radioactivity was released.

04/02/85 A tractor-trailer transporting LLW was traveling on I-390 in Livingston County in New York when it slid into a guard rail on an icy bridge. The driver braked to avoid an accident ahead and the trailer jackknifed. The shipment included pumps and equipment, which remained intact and undamaged. No radioactivity was released. 
04/11/85 A tractor-trailer transporting LLW en route from the Peach Bottom Nuclear Power Plant in Pennsylvania to Richland, Washington, was traveling on US 11/15 in Enola, Pennsylvania, when it was involved in a traffic accident. As a result, the tractor trailer sustained minor damage. The shipment included 14 metal boxes containing LLW. The shipment was not damaged and no radioactivity was released.

01/16/86 A tractor-trailer transporting LLW en route from a company in Washington to Richland, Washington, was traveling on Hwy 243, near Mattawa, Washington, when the truck skidded on black ice and the trailer jackknifed but did not overturn. The shipment included 3055 -gallon steel drums containing carbon-14, iodine-125, iodine-131, chromium51 , and phosphorus-32. The drums remained intact and undamaged. No radioactivity was released.

03/15/86 A tractor-trailer transporting LLW was traveling in Brooklyn, New York, when it became wedged under elevated railroad tracks. The truck was 13 feet high, but the tracks were only 12 feet high. The driver was cited for not following the designated DOT route for hazardous materials (radioactive materials) and for reckless endangerment. The shipment included 24655 -gallon steel drums. The drums were not damaged but were transferred to another vehicle while the wedged truck was freed. No radioactivity was released.

03/28/87 A tractor-trailer transporting solidified filters en route from LaSalle, Illinois, to Beatty, Nevada, had stopped for the night during a snow storm in Des Moines, Iowa. During the night, the driver was awakened to move the rig. When he moved the truck the rear axle slid into a ditch. The shipment included a 70-thousand-pound Type A cask, which was undamaged. No radioactivity was released.

05/19/89 A tractor-trailer transporting LLW en route from Harrisburg, Pennsylvania, to Richland, Washington, was traveling on Rt 90, east of Bozeman, Montana, when a passenger car that was passing on the right went out of control. The car struck the front tire and fuel saddle tank. The truck managed to stop and make repairs without further incident. The shipment included a Type B cask containing Class C LLW en route to Richland, Washington. The cask was undamaged and no radioactivity was released. 


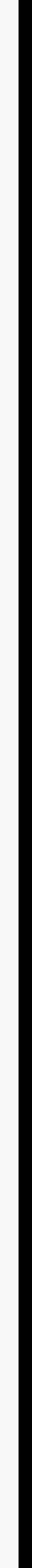

